\title{
Effect of non-thermal processing techniques on pathogenic and spoilage microorganisms of milk and milk products
}

\author{
Muhmmad Asim SHABBIR ${ }^{1}$, Haassan AHMED ${ }^{1}$, Abid Aslam MAAN ${ }^{1,2}$, Abdur REHMAN ${ }^{3}$, \\ Muhammad Talha AFRAZ1 ${ }^{1}$, Muhammad Waheed IQBAL ${ }^{3}$, Imran Mehmood KHAN ${ }^{3}$ (D), Rai Muhammad AMIR ${ }^{4}$, \\ Waqas ASHRAF ${ }^{3}$, Moazzam Rafiq KHAN ${ }^{1 *}$, Rana Muhammad AADIL ${ }^{1}$ (D)
}

\begin{abstract}
Milk is a nutritious perishable product having a short shelf-life owing to the occurrence of spoilage bacteria in it. This has led to an increasing demand for ensuring safety through milk processing. Conventional techniques (such as heat treatment) increase shelf-life but damage the nutritional and sensory qualities of milk. Hence, there is a need to develop innovative, nonthermal processing techniques that increase the shelf-life while preserving its nutritional quality. This review focuses on the recent advances in assuring microbial safety of milk by using nonthermal techniques such as high-pressure processing, pulsed electric fields, ultrasound, ultraviolet irradiation and membrane microfiltration.

Keywords: microbial inactivation; emerging technologies; ultrasound; pulsed electric field; milk processing.

Practical Application: In milk industry, different types of thermal treatments are already applicable to reduce the microbial activity, but it has some nutritional losses due to heat treatment. But the same microbial reduction can be achieved (less nutritional losses) after mild heat treatments such as high-pressure processing, pulsed electric fields, ultrasound, ultraviolet irradiation and membrane microfiltration, which are the best substitute of thermal treatments. This article will be helpful for the milk processing industries to apply these nonthermal treatments for the best processing of milk at industry level.
\end{abstract}

\section{Introduction}

Milk is a perishable food having high moisture contents and all nutrients that helps microorganisms to proliferate. To maximize consumer safety and product quality, nonthermal processing technologies are gaining popularity in the dairy industry (Barba et al., 2017; Misra et al., 2017; Manzoor et al., 2019a, b; Monteiro et al., 2018; Ahmad et al., 2019a). The consumer demand is increasing for minimally processed and fresh-like foods with natural tastes (Roobab et al., 2018; Aadil et al., 2013, 2015a, b; Ahmad et al., 2019b). Despite the associated health hazards, some consumers still prefer to consume raw milk due to its "healthy" claims and natural, refreshing taste. Hence, the new dairy processing techniques are a need for providing both fresh and nutritious as well as safe foods with better storage stability (Alegbeleye et al., 2018; Li \& Farid, 2016).

The microbial inactivation during milk processing is crucial for enhancing the shelf-life and stability of milk because milk contains nutrients that support the microbial activity and growth (Claeys et al., 2013; Monteiro et al., 2020). In the dairy industry, thermal treatments i.e., pasteurization, sterilization, ultra-high temperature have been intensively investigated to inactivate or destroy the pathogenic and spore-forming microorganisms in dairy products (Guimarães et al., 2019). Utilization of raw milk or its products (which are associated with many pathogens including
Listeria monocytogenes, Staphylococcus aureus, Escherichia coli O157: H7, Bacillus cereus, Salmonella spp., Campylobacter spp., Clostridium botulinum) is one of the major courses for the occurrence of foodborne illness worldwide (Claeys et al., 2013; Aadil et al., 2015c, d). Thermal treatment of milk can destroy the amount of some nutritional components along with some undesirable flavour changes. Considering these nutritional and organoleptic changes, novel nonthermal technologies (including high-pressure processing (HPP), pulsed electric field (PEF), ultrasound, ultraviolet irradiations, nonthermal plasma (cold plasma) and membrane microfiltration) have been developed with ability to inactivate both the pathogenic and spoilage microorganisms (Claeys et al., 2013; Amaral et al., 2018; Guimarães et al., 2018, 2019; Coutinho et al., 2019a, b; Zia et al., 2019; Aadil et al., 2018, 2020). The objective of this review is to give a comprehensive overview of the application of nonthermal techniques in milk and milk products together with their effects on nutritional, organoleptic and microbial quality of the product.

\section{High-Pressure Processing (HPP)}

In contrast to thermal processing technologies where temperature has a main influence in the inactivation of microbes and certain enzymes of interest, HPP employ high pressure generally 
100-600 MPa for up to 20 min of duration to eliminate certain pathogenic microorganisms to increase the shelf life of liquid and solid foods (Evelyn \& Silva, 2015). The application of this non-thermal technique is not new and has been long employed in various non-food industries (Oliveira et al., 2012). Application of HPP on food was first reported in the late nineteenth century. Although, the commercialization of this non-thermal technique is recent, as reflected by the increase in number of HPP units installed around the world, but its application on foods has been studied for over 100 years (Sousa et al., 2016). It has been assessed that HPP can alter the characteristics of food proteins, this alteration depends upon the power employed, duration of treatment and temperature. It causes irreversible changes in secondary, tertiary and quaternary structures of protein by affecting mostly the covalent bonds (Dhakal et al., 2014).

\subsection{Application in the dairy industry}

HPP minimizes the nutrient loss and effects the activity of microbes. When skim milk is subjected to HPP treatment $(300 \mathrm{MPa})$, it was found that the particles size substantially decreases, with the decrease of average size from about 200 to $100 \mathrm{~nm}$ regardless of temperature during pressurization. However, pasteurization temperature, $\mathrm{pH}$ of the milk, a pressure range of 200 and $300 \mathrm{MPa}$, and pressure treatment time affect the increase in the size of the particle (Anema et al., 2005). In milk, HPP at mild and room temperature, disorders only those chemical bonds that are moderately weak such as ionic bonds, hydrogen bonds and hydrophobic bonds. The small molecules such as simple-sugars, amino-acids, vitamins and flavour components remain unchanged after HPP treatment (Cheftel, 1992). Sierra et al. (2000) have reported that treatment of milk with HPP causes non-significant vitamin (B1, B6) loss at $400 \mathrm{MPa}$ (at a rate of $2.5 \mathrm{MPa}$ for $30 \mathrm{~min}$ at $25^{\circ} \mathrm{C}$ ). Also, the reduction in proteolytic activity was also observed due to HPP treatment (400 MPa, $40-60{ }^{\circ} \mathrm{C}$ and $15 \mathrm{~min}$ ). In terms of maintaining the milk organoleptic properties at $25-60{ }^{\circ} \mathrm{C}$, it was suggested that these treatments in combinations could be useful to produce the milk having an increased shelf-life with good sensory properties (García et al., 1989).

\subsection{Effect on milk quality}

Harte et al. (2003) showed that L-value of milk was reduced by HPP due to the disintegration of casein micelles, which cause the reduction in turbidity of milk. The slight effect on L-value was observed when milk was subjected to $200 \mathrm{MPa}$, while at 250-450MPa pressure there is a significant decrease in the L-value. At $600 \mathrm{MPa}$ for $30 \mathrm{~min}$, skim milk showed a decline in L-value from 78 to 42 and skim milk establishes a semi-transparent or translucent appearance (Naik et al., 2013).

HPP causes the reduction in time required for the induction of fat crystallization and this is because the value at high-pressure liquid/solid transition temperature of milk fat moves to high. At HPP treatment $\left(100 \mathrm{MPa}, 16.3^{\circ} \mathrm{C}\right)$, there was an increase in the melting temperature as well as crystallization temperature of milk fat also increased at $15.5^{\circ} \mathrm{C}$ with same pressure. Hence, higher the solid fat content present in HPP treated cream than untreated cream, also the time reduction in aging of ice cream substantially. Accordingly, even up to $800 \mathrm{MPa}$ milk fat globule membrane (MFGM) was not deteriorate after applying HPP treated milk. After HPP treatment of milk fat globule, mean diameter of this globule remains unaffected. After HPP treatment, there is no increase in lipolysis, but some whey proteins were absorbed into the MFGM and the membrane remains undamaged (Naik et al., 2013).

\subsection{Effect on microbes}

Table 1 summarises the effect of HPP treatment on milk microorganisms. HPP played an important role in the inactivation of microbial activities due to applied pressure and temperature on various microorganisms such as E. coli, L. innocua, L. monocytogenes, S. aureus, Bacillus spores or different traits of these microorganisms in milk. As a result of HPP treatment (300 $\mathrm{MPa}, 84^{\circ} \mathrm{C}$ on skim milk) a $0.67-\log$ reduction of Bacillus stearothermophilus ATCC 7953 and Clostridium sporogenes PA3679 (Pinho et al., 2011). When HPP treatment (400 MPa, 21 to $31{ }^{\circ} \mathrm{C}$ and 0 to $50 \mathrm{~min}$ ) was applied to human milk, L. monocytogenes ATCC 19115, and Staphylococcus aureus ATCC 25923 was reduced by 6-log and 8-log, respectively (Viazis et al., 2008). Similarly, when a commercial sterile milk was treated with $\mathrm{HPP}\left(300 \mathrm{MPa}, 75-85^{\circ} \mathrm{C}\right)$, an approximate reduction of $5 \mathrm{CFU} / \mathrm{mL}$ of Bacillus spores was reported (Amador Espejo et al., 2014).

Patterson et al. (1995) demonstrated that D value of Salmonella typhimurium was $3 \mathrm{~min}$ when $350 \mathrm{MPa}$ pressure and first-order rate constant $(\mathrm{K}(1 / \mathrm{min})=0.768)$ was applied on milk. Similarly, D value (3 min) of Yersinia enterocolitica was observed after applying a pressure of $275 \mathrm{MPa}(\mathrm{K}(1 / \mathrm{min})=0.768)$. The $\mathrm{D}$ value of $L$. monocytogenes was reduced to $3 \mathrm{~min}$ when $375 \mathrm{MPa}$ pressure and $(\mathrm{K}(1 / \mathrm{min})=0.768)$ applied in milk. In milk, HPP has also reduced the E. coli and $S$. aureus when such conditions applied $\left(400 \mathrm{MPa}, 50{ }^{\circ} \mathrm{C}(\mathrm{K}(1 / \mathrm{min})=0.768)\right.$. The strain E. coli O157:H7 gave the $\mathrm{D}$ value (3 min). After increasing the pressure $\left(500 \mathrm{MPa}, 50{ }^{\circ} \mathrm{C}(\mathrm{K}(1 / \mathrm{min})=0.92)\right.$ $S$. aureus showed a D value of 2.5 min (Patterson \& Kilpatrick, 1998). Erkmen (2009) observed $9.21 \mathrm{~min}$ D value in Salmonella typhimurium when $300 \mathrm{MPa}$ at $25^{\circ} \mathrm{C}$ was applied on raw milk. After increasing the pressure $(700 \mathrm{MPa})$ and temperature $\left(90^{\circ} \mathrm{C}\right)$, C. sporogenes was reduced to $13.6 \mathrm{~min}$ of $\mathrm{D}$ value (Shao \& Ramaswamy, 2011).

A 3.50-log reduction of E. coli (MG 1655) was observed in raw milk with $15 \%$ fat subjected to HPP treatment (300 MPa, $25^{\circ} \mathrm{C}$ ) (Diels et al., 2005). Picart et al. (2006) has reported that L. innocua reduced to $1.80-\log$ in raw milk with $15 \%$ fat, when treated with $300 \mathrm{MPa}$ at $24{ }^{\circ} \mathrm{C}$. There was an effective pressure treatment for periodic oscillation with a condition of 200 to $500 \mathrm{MPa} / 60 \mathrm{~min}, 20^{\circ} \mathrm{C}$ in destroying pathogenic microorganisms such as Salmonella enteritidis, L. monocytogenes and E. coli (Vachon et al., 2002). HPP treatment (500 to $600 \mathrm{MPa}$, $10 \mathrm{~min}$ at $25^{\circ} \mathrm{C}$ ) was needed to deactivate the Gram-positive bacteria while Gram-negatives were deactivated at relatively lower temperature, pressures and time (Smelt, 1998).

When UHT milk was treated with HPP for the inactivation of B. cereus, $P$. fluorescens and L. monocytogenes, there was less resistance of exponential phase cells to pressure as compared 
Table 1. Effect of HPP on different microbes in milk.

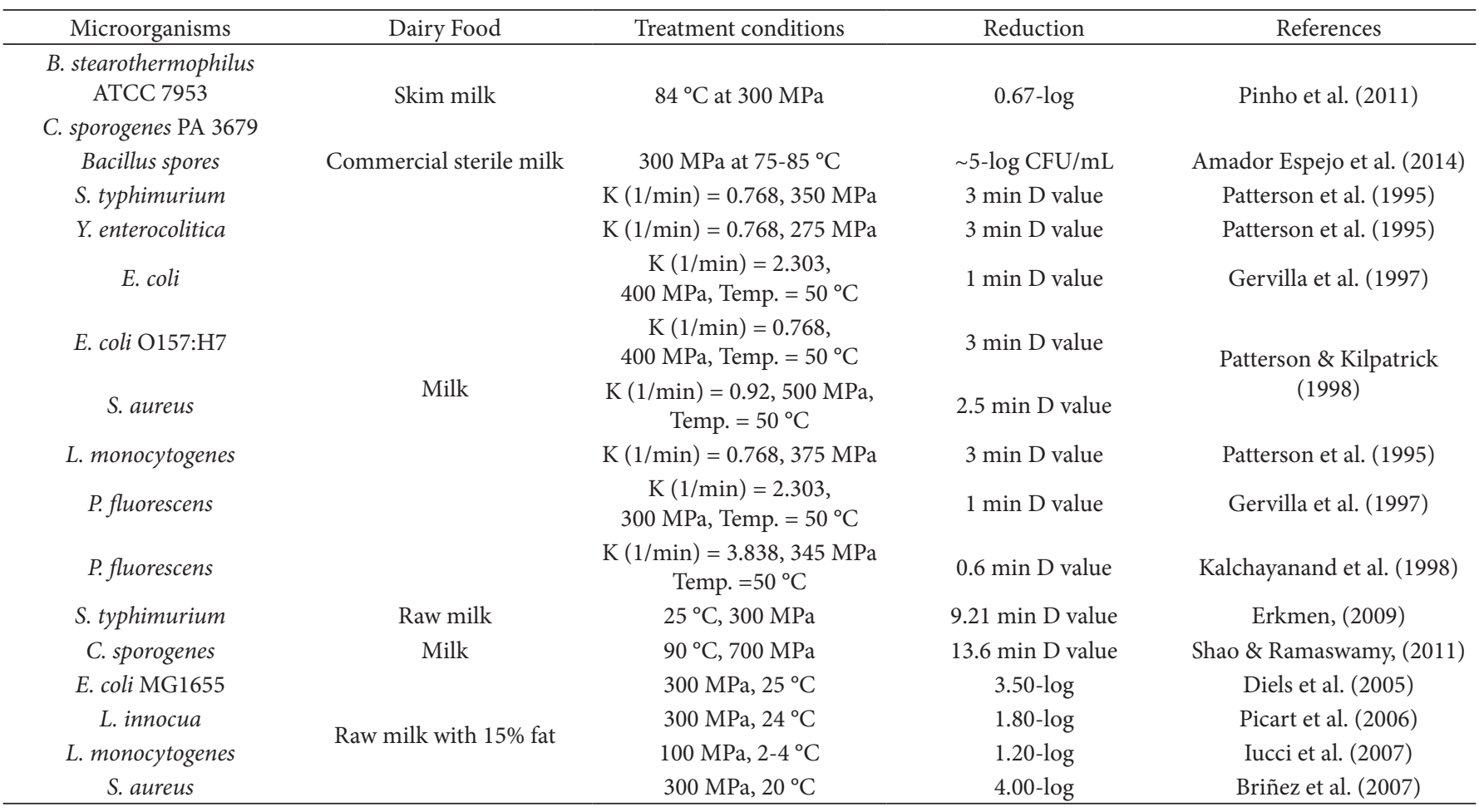

to cells having stationary phase. At $8^{\circ} \mathrm{C}$, exponential cells were more resistant in comparison to those grown at $30^{\circ} \mathrm{C}$, while the reverse was applicable for the cells in the stationary phase. In the stationary growth phase at $30^{\circ} \mathrm{C}, \mathrm{B}$. cereus cells were the most pressure resistant. The most sublethal damages were observed for L. monocytogenes in comparison with P. fluorescence and B. cereus (McClements et al., 2001). While Chen \& Hoover (2003) has investigated that UHT processed whole milk by HPP for the inactivation of L. monocytogenes Scott A unveiled that higher temperatures considerably enhanced the pressure caused the inactivation of $L$. monocytogenes. The endospores are highly resistant as compared to vegetative cells against HPP treatment, but a complete inactivation required a pressure $>1000 \mathrm{MPa}$ and $>80^{\circ} \mathrm{C}$ (Rastogi et al., 2007). Thus, it is proved that HPP in combination with heat, can inactivate the bacterial spores more effectively than HPP alone (Black et al., 2011), and spores were more sensitive to successive pressure treatments when germinated at lower pressures (Setlow et al., 2001). At HPP treatment of $400 \mathrm{MPa}$ for $25 \mathrm{~min}$ at $30^{\circ} \mathrm{C}$, B. cereus spores were more repellent to pressure in comparison to vegetative cells, and $0.45-\log \mathrm{CFU} / \mathrm{mL}$ decrease in spores of this bacterium was obtained. McClements et al. (2001) have reported that less spore germination induced at $8{ }^{\circ} \mathrm{C}$ than by pressure treatment while the inactivation of the most vegetative yeasts and molds are caused when the pressure of $300-400 \mathrm{MPa}$ at $25^{\circ} \mathrm{C}$ was applied for a few minutes.

\section{Pulsed Electric Fields (PEF)}

Pulsed electric filed (PEF), gained popularity as a potential tool for the inactivation of microorganisms especially in liquid foods (Pal, 2017). PEF has promising effect on the removal of both pathogenic and spoilage causing microbes, and enzymes related to the quality deterioration without causing any decrease in consumer demands (Alirezalu et al., 2020). This technique has major edge of providing high quality food and claimed as superior to traditional thermal processing as it decreases destructive changes in nutritional profile, quality, sensorial and physical attributes of food (Syed et al., 2017). PEF induced inactivation of certain enzymes and microbes is considered to be due to the electroporation and dielectric breakdown of cell membrane. This process is affected by some factors, such as number of pulses, electric field intensity, pulse width, flow rate and shape. Besides that, parameters like temperature, conductivity and physiological parameters of microbes (Sharma et al., 2014) also affect the process. The simple working principle of PEF is based on the application of high electric fields (cause inactivation of organisms) in the form of short pulses at an intensity of $10-80 \mathrm{kV} / \mathrm{cm}$ for the duration of micro-seconds. By multiplying the actual number of pulses with effective pulse duration, one can calculate processing time. As the electric field is applied, current flows into the liquid food sample and transferred to each point because of the presence of charged molecules. After the treatment, food needs to be packed aseptically and cold storage should be maintained in order to get longer shelf claims (Pal, 2017).

\subsection{Application in the dairy industry}

PEF treatment ( $35 \mathrm{kV} / \mathrm{cm}, 3 \mu$ s pulse width, $9 \mu \mathrm{s})$ of raw skim milk did not show any significant difference in proteins, colour, moisture and $\mathrm{pH}$ (Michalac et al., 2003). PEF treatment $\left(35 \mathrm{kV} / \mathrm{cm}, 2.3 \mu\right.$ s width of the pulse at $65^{\circ} \mathrm{C}$ for $<10 \mathrm{sec}$ ) immediately after high temperature short time (HTST) 
pasteurization has enhanced the milk shelf-life up to 78 days at $4{ }^{\circ} \mathrm{C}$ (Sepulveda-Ahumada, 2003). PEF treatment of bovine immunoglobulin (IgG) enriched soymilk at a dose of $41 \mathrm{kV} / \mathrm{cm}$ for $54 \mu$ s did not cause any change in bovine IgG activity but resulted in a 5.3-log reduction of initial microbial-flora (Li et al., 2003). Sensory properties of PEF treated dairy products are similar to thermally treated counterparts and reported to have a good consumer acceptance rate (Sobrino-López \& Martin-Belloso, 2006).

\subsection{Effect on milk quality}

As a novel technique, only few reports are related to nutritional properties such as vitamin or protein contents, while some of these reports include brief studies on sensorial quality such as taste and flavour of milk. Among these, studies on vitamin content in milk, water-soluble vitamins (riboflavin, vitamin $\mathrm{C}$, and thiamine) and fat-soluble vitamins (tocopherol, cholecalciferol) were analysed after $400 \mu$ s at $18.3-27.1 \mathrm{kV} / \mathrm{cm}$. Significant changes for vitamin contents were not reported in milk (Bendicho et al., 2002). The significant changes in the food quality generated by the interaction with electric current discharge into the electrode are in the chemical structure of liquids, which are mainly generated very close to the electrode surface. The important products formed due to the breakdown of water molecules (Morren et al., 2003) and other food components at the interface of electrode-food (Saulis et al., 2007). A significant difference $(\mathrm{p}<0.05)$ was noticed between raw milk and PEF treated milk and in their physicochemical properties. The reduction in solids non-fat contents can be attributed to the electrodeposition of milk materials on the surface of electrode which may form a rubber layer. The solids non-fat are commonly called serum solids (Potter, 1986) including casein, lactose, lactalbumin, phosphorus, calcium and riboflavin (International Dairy Foods Association, 2006).

\subsection{Effect on milk microbes}

Table 2 shows the effect of PEF treatment on the inactivation of microorganisms in milk. Qin et al. (1998) have observed that $E$. coli were treated with $\mathrm{PEF}(26 \mathrm{kV} / \mathrm{cm}$ and $60 \mathrm{kV} / \mathrm{cm}$ at $400 \mu$ s and $40^{\circ} \mathrm{C}$ with exponential decay pulses) in stimulated milk ultra filtrate (SMUF) having a 6 and 8 -log reduction. Fernández-Molina et al. (1999a) reported a 2.6-2.7-log cycles reduction of $L$. innocua when pasteurized skim milk treated with PEF $(200 \mu$ s at $50 \mathrm{kV} / \mathrm{cm})$. In SMUF, a $6-\log$ reduction of E. coli was reported after PEF treatment $(36 \mathrm{kV} / \mathrm{cm}, 50$ pulses $)$ (Qin et al., 1998). (Fernández-Molina et al., 1999a) showed the effect of PEF $\left(15\right.$ to $28{ }^{\circ} \mathrm{C}$ and $0.5 \mathrm{~L} / \mathrm{min} 100$ pulses with $50 \mathrm{kV} / \mathrm{cm}, 0.5 \mu \mathrm{F}, 2 \mu \mathrm{sec}, 3.5 \mathrm{~Hz}$ exponential decay) and reached to 2.6-log reduction of L. innocua in raw skim milk having milk fat (0.2\%). Qin et al. (1995) have reported a 7-log reduction of E. coli in SMUF with this treatment $\left(<30^{\circ} \mathrm{C}, 2.5 \mathrm{~V} / \mu \mathrm{m}\right.$, \pm 300 pulses and $20 \mu$ s exponential decay pulse width). When raw bovine milk treated with $\operatorname{PEF}(89 \mu \mathrm{s}$ at $40 \mathrm{kV} / \mathrm{cm}$ and $89 \mu$ s at $40 \mathrm{kV} / \mathrm{cm}$ at $32.5^{\circ} \mathrm{C}$ ), E. coli $\mathrm{K} 12$ was reduced to $5-\log$ and S. aureus was reduced to 5.2-log (Halpin et al., 2013), while L. innocua in raw skim milk was reduced to 4.3-log after PEF treatment (30-pulses of $40 \mathrm{kV} / \mathrm{cm}, 10 \mathrm{~s}$ at $53^{\circ} \mathrm{C}$ ) (Guerrero-Beltrán et al.,
2010). In milk (skim), Lactococcus lactis was reduced after PEF treatment $\left(35 \mathrm{kV} / \mathrm{cm}, 90 \mu \mathrm{s}\right.$ at $\left.22^{\circ} \mathrm{C}\right)$ that cause $1-\log$ reduction (Michalac et al., 2003) and 3.3-log reduction of L. innocua after a PEF treatment $\left(40 \mathrm{kV} / \mathrm{cm}, 50 \mu\right.$ sat $10^{\circ} \mathrm{C}$ ) (Noci et al., 2009). E. coli showed 38.4-44.8 $\mu \mathrm{D} \mathrm{D}$ value when the rate of first-order constant $\mathrm{K}(\mathrm{x} 10-2 / \mu \mathrm{s})=5.14-6.0$ and $20-45 \mathrm{kV} / \mathrm{cm}$ field is applied on skim milk (Martin et al., 1997). Additionally, in skim milk under conditions having a rate constant of $\mathrm{K}(\mathrm{x} 10-2 / \mu \mathrm{s})=0.054-0.52$, pulsed of $15-40 \mathrm{kV} / \mathrm{cm}$, and temperature of $15-40{ }^{\circ} \mathrm{C}$ gave the $4-42.4 \mu$ s $\mathrm{D}$ value for Salmonella dublin (Sensoy et al., 1997).

Lactobacillus delbrueckii and B. subtilis was reduced with the help of using $\mathrm{K}(\mathrm{x} 10-2 / \mu \mathrm{s})=0.096-0.115$, pulses of $16 \mathrm{kV} / \mathrm{cm}$ and temperature $\left(<30^{\circ} \mathrm{C}\right)$ and $\mathrm{K}\left(\mathrm{x} 10^{-2} / \mu \mathrm{s}\right)=$ $0.077-0.092,16 \mathrm{kV} / \mathrm{cm}$, temperature $<30{ }^{\circ} \mathrm{C}$ showed the D value of 2000-2400 $\mu$ s and 2500-3000 $\mu$ s respectively in SMUF (Swanson et al., 1995). At ambient temperature with $2 \mu$ s, 100 pulses at $50 \mathrm{kV} / \mathrm{cm}, 2.6$ and 2.7-log reductions were observed in different micro-organisms (Fernández-Molina et al., 1999b). According to Zhao et al. (2013), E. coli and L. monocytogenes in raw whole milk treated with PEF ( $25 \mathrm{kV} / \mathrm{cm}$ for $200 \mu \mathrm{s})$ showed a 2.1-log reduction of E. coli and 5-log cycles of $L$. monocytogenes (30 kV/cm after $200 \mu \mathrm{s})$. UHT milk was subjected to 150 (bipolar) pulses of $8 \mu$ at $35 \mathrm{kV} / \mathrm{cm}$ and caused a $4.5-\log$ reduction in S. aureus (Sobrino-López \& Martin-Belloso, 2006). L. innocua in raw skim milk was reduced with the help of 2 us, 100 pulses, $50 \mathrm{kV} / \mathrm{cm}$ at ambient temperature, and almost 2.4 to $3.4-\log$ reduction was reported (Miranda, 1998).

Mañas et al. (2001) reported 2-log reduction of E. coli in cream through application of PEF $(33 \mathrm{kV} / \mathrm{cm}$, below $100 \mu \mathrm{s})$, and (Evrendilek \& Zhang, 2005) has indicated the equivalent reduction of E. coli O157:H7 in PEF treated skim milk $(24 \mathrm{kV} / \mathrm{cm}$ for $141 \mu \mathrm{s})$. In PEF treated skim milk $(25 \mathrm{kV} / \mathrm{cm}$ for $45 \mu \mathrm{s}$ ), a decrease in E. coli bacteria was more than 2-log cycles (Martin et al., 1997). In UHT skim milk, >4-log cycles of E. coli cells were inactivated after PEF treatment $(22.4 \mathrm{kV} / \mathrm{cm}$ for $46 \mu \mathrm{s})$ (Grahl \& Märkl, 1996). In pasteurised fat-free milk inoculated with $E$. coli prior to PEF treatment $(41 \mathrm{kV} / \mathrm{cm}$ for $158 \mu \mathrm{s})$, more than 5.5-log cycles did not survive in these processing conditions (Dutreux et al., 2000). In simulated milk ultra-filtrate (SMUF), a reduction of up to 9-log cycles of E. coli was observed (Zhang et al., 1995) after PEF treatment $(70 \mathrm{kV} / \mathrm{cm}$ for $160 \mu \mathrm{s})$.

\section{Ultrasound}

Ultrasound (US) technology is one of the most widely used non-thermal processing technique around the world because of its environment friendly, non-toxic and benign nature, additionally it has a wide range of applications in food industry (Shanmugam et al., 2012). It has been a century that we know the destructive effect of US on both pathogenic and spoilage causing microorganisms, but induction of this technology in food industry for controlling and promoting their activities is much more recent. Firstly, Harvey \& Loomis (1929) reported significant effect of US to kill luminous bacteria in aqueous medium (Ojha et al., 2017). US technology was applied in food industry because of its ability to improve 
Shabbir et al.

Table 2. Effect of PEF on different microbes in milk.

\begin{tabular}{|c|c|c|c|c|}
\hline Microorganisms & Dairy food & Treatment conditions & Reduction & References \\
\hline E. coli & $\begin{array}{l}\text { Milk submitted to } \\
\text { ultrafiltration }\end{array}$ & $\begin{array}{l}50 \text { pulses of } 60 \mathrm{kV} / \mathrm{cm} \text { or } \\
80 \text { pulses of } 70 \mathrm{kV} / \mathrm{cm}\end{array}$ & 6 and 9-log & Qin et al. (1998) \\
\hline L. innocua & Pasteurized skim milk & $200 \mu \mathrm{s}$ at $50 \mathrm{kV} / \mathrm{cm}$ & 2.6-2.7-log & Fernández-Molina (2001) \\
\hline $\begin{array}{l}\text { E. coli } \mathrm{K} 12 \\
\text { S. aureus }\end{array}$ & Raw bovine milk & $89 \mu \mathrm{s}$ at $40 \mathrm{kV} / \mathrm{cm}$ at $32.5^{\circ} \mathrm{C}$ & $\begin{array}{r}5-\log \\
5.2-\log \end{array}$ & $\begin{array}{l}\text { Cregenzán-Alberti et al. } \\
\text { (2015) }\end{array}$ \\
\hline E. Coli & Raw whole milk & $25 \mathrm{kV} / \mathrm{cm}$ for $200 \mu \mathrm{s}$ & $2.1-\log$ & Zhao et al. (2013) \\
\hline $\begin{array}{l}\text { L. monocytogenes } \\
\text { S. aureus }\end{array}$ & $\begin{array}{l}\text { Raw whole milk } \\
\text { UHT milk }\end{array}$ & $\begin{array}{c}30 \mathrm{kV} / \mathrm{cm} \text { after } 200 \mu \mathrm{s} \\
150 \text { bipolar pulses of } 8 \mu \mathrm{s} \text { at } \\
35 \mathrm{kV} / \mathrm{cm}\end{array}$ & $\begin{array}{r}5-\log \\
4.5-\log \end{array}$ & $\begin{array}{l}\text { Zhao et al. (2013) } \\
\text { Sobrino-López \& Martin- } \\
\text { Belloso (2006) }\end{array}$ \\
\hline L. innocua & Raw skim milk & $\begin{array}{c}2 \mu \mathrm{sec}, 100 \text { pulses, } 50 \mathrm{kV} / \mathrm{cm} \text { at } \\
\text { ambient temperature }\end{array}$ & 2.4-log & Calderon-Miranda (1998) \\
\hline E. coli & UHT milk & 15 pulses, $22 \mathrm{kV} / \mathrm{cm}$ & $3-\log$ & Grahl et al. (1992) \\
\hline E. coli & Stimulated milk ultrafiltrate & $36 \mathrm{kV} / \mathrm{cm}, 50$ pulses & 6-log & Qin et al. (1998) \\
\hline L. innосиа & Raw skim milk & $\begin{array}{c}15 \text { to } 28^{\circ} \mathrm{C}, 0.5 \mathrm{~L} / \mathrm{min} \\
100 \text { pulses, } 50 \mathrm{kV} / \mathrm{cm} 0.5 \mu \mathrm{F} \\
2 \mu \mathrm{sec}, 3.5 \mathrm{~Hz} \text { Exponential decay }\end{array}$ & $2.6-\log$ & $\begin{array}{l}\text { Fernández-Molina et al. } \\
\qquad(1999 a)\end{array}$ \\
\hline E. coli & Skim milk & $\begin{array}{c}15 \pm 1{ }^{\circ} \mathrm{C}, 4.0 \mathrm{~V} / \mu \mathrm{m}, 3 \mu \mathrm{sec} \\
64 \text { Pulses }\end{array}$ & 3-log & Zhang et al. (1994) \\
\hline E. coli & Stimulated milk ultrafiltrate & $\begin{array}{c}<30^{\circ} \mathrm{C}, 1.6(1.2,1.4,1.6 \text { tested }) \\
\mathrm{V} / \mu \mathrm{m}, 200-300 \mu \mathrm{sec} \\
60(20,30,40,50,60) \text { pulses }\end{array}$ & $4-\log$ & Pothakamury et al. (1995) \\
\hline E. coli & SMUF & $\begin{array}{c}<30^{\circ} \mathrm{C}, 2.5 \mathrm{~V} / \mu \mathrm{m}, \pm 300 \text { pulses } \\
\text { exponential decay pulse width } \\
20 \mu \mathrm{sec}\end{array}$ & 7-log & Qin et al. (1995) \\
\hline L. lactis & Skim milk & $35 \mathrm{kV} / \mathrm{cm}, 90 \mu \mathrm{s}, 22^{\circ} \mathrm{C}$ & 1-log & Michalac et al. (2003) \\
\hline L. innocua & Milk & $40 \mathrm{kV} / \mathrm{cm}, 50 \mu \mathrm{s}, 10^{\circ} \mathrm{C}$ & 3.3-log & Noci et al. (2009) \\
\hline E. coli & Skim milk & $\begin{array}{c}\mathrm{K}(\mathrm{x} 10-2 / \mu \mathrm{s})=5.14-6.0 \\
20-45 \mathrm{kV} / \mathrm{cm}\end{array}$ & $38.4-44.8 \mu$ s D value & Martin et al. (1997) \\
\hline Salmonella Dublin & Skim milk & $\begin{array}{c}\mathrm{K}\left(\mathrm{x} 10^{-2 /} \mu \mathrm{s}\right)=0.054-0.52 \\
15-40 \mathrm{kV} / \mathrm{cm}, \mathrm{Temp}=15-40{ }^{\circ} \mathrm{C}\end{array}$ & $4-42.4 \mu$ s D value & Sensoy et al. (1997) \\
\hline L. monocytogenes $(\mathrm{Scott} \mathrm{A})$ & Milk & $\begin{array}{c}\mathrm{K}\left(\mathrm{x} 10^{-2} / \mu \mathrm{s}\right)=0.012-0.015 \\
30 \mathrm{kV} / \mathrm{cm}, \mathrm{Temp}=10-50^{\circ} \mathrm{C}\end{array}$ & $150-200 \mu$ s D value & Reina et al. (1998) \\
\hline L. innocua & Skim milk & $\begin{aligned} \mathrm{K}(\mathrm{x} 10-2 / \mu \mathrm{s}) & =2.995,50 \mathrm{kV} / \mathrm{cm} \\
\mathrm{Temp} & =15-28^{\circ} \mathrm{C}\end{aligned}$ & $76.9 \mu$ s D value & $\begin{array}{l}\text { Fernández-Molina et al. } \\
\text { (1999a) }\end{array}$ \\
\hline L. delbrueckii & $\begin{array}{c}\text { SMUF } \\
\text { Raw skim milk }(0.2 \% \text { milkfat })\end{array}$ & $\begin{array}{c}\mathrm{K}(\mathrm{x} 10-2 / \mu \mathrm{s})=0.096-0.115 \\
16 \mathrm{kV} / \mathrm{cm} \mathrm{Temp},<30^{\circ} \mathrm{C}\end{array}$ & $2000-2400 \mu$ s D value & Pothakamury, (1995) \\
\hline B. subtilis & & $\begin{array}{c}\mathrm{K}(\mathrm{x} 10-2 / \mu \mathrm{s})=0.077-0.092 \\
16 \mathrm{kV} / \mathrm{cm}, \mathrm{Temp}<30{ }^{\circ} \mathrm{C}\end{array}$ & $2500-3000 \mu$ s D value & $\begin{array}{l}\text { Pothakamury, (1995) } \\
\text { Qin et al. (1994) }\end{array}$ \\
\hline $\begin{array}{l}\text { B. subtilis } \\
\text { P. fluorescens }\end{array}$ & SMUF & $\begin{array}{c}\mathrm{K}(\mathrm{x} 10-2 / \mu \mathrm{s})=0.44-0.54 \\
16 \mathrm{kV} / \mathrm{cm}\end{array}$ & $425-520 \mu$ s D value & Pothakamury, (1995) \\
\hline $\begin{array}{l}\text { B. subtilis } \\
\text { P. fluorescens }\end{array}$ & $\begin{array}{c}\text { Raw skim milk (0.2\% milkfat) } \\
\text { Milk }\end{array}$ & $\begin{array}{c}15-28^{\circ} \mathrm{C}, 0.51 / \mathrm{min} 30 \text { pulses, } \\
50 \mathrm{kV} / \mathrm{cm}, 0.5 \mu \mathrm{F}, 2 \mu \mathrm{sec} \\
4.0 \mathrm{~Hz} \text { Exponential decay }\end{array}$ & $2.7-\log$ & $\begin{array}{l}\text { Qin et al. (1994) } \\
\text { Fernández-Molina et al. } \\
\text { (1999b) }\end{array}$ \\
\hline S. Dublin & & $\begin{array}{c}63{ }^{\circ} \mathrm{C}, 3.67 \mathrm{~V} / \mu \mathrm{m}, 36 \mu \mathrm{sec} \\
40 \text { pulses }\end{array}$ & 4.0-log & Dunn \& Pearlman (1987) \\
\hline Lactobacillus brevis & Yogurt & $\left(50^{\circ} \mathrm{C}, 1.8 \mathrm{~V} / \mu \mathrm{m}\right.$ & 2.0- $\log$ & Dunn \& Pearlman (1987) \\
\hline B. stearothermophilus & $3.4 \%$ fat milk & $60 \mathrm{kV} / \mathrm{cm}, 200 \mu \mathrm{s}, 50^{\circ} \mathrm{C}\left(\mathrm{T}_{\mathrm{in}}\right)$ & $3-\log$ & Shin et al. (2007) \\
\hline L. lactis & Skim milk & $35 \mathrm{kV} / \mathrm{cm}, 90 \mu \mathrm{s}, 22^{\circ} \mathrm{C}$ & $1-\log$ & Michalac et al. (2003) \\
\hline P. fluorescens & $3.4 \%$ fat milk & $60 \mathrm{kV} / \mathrm{cm}, 200 \mu \mathrm{s}, 40^{\circ} \mathrm{C}\left(\mathrm{T}_{\mathrm{in}}\right)$ & $5-\log$ & Shin et al. (2007) \\
\hline Cronobacter sakazakii & Infant formula milk & $35 \mathrm{kV} / \mathrm{cm}, 500 \mu \mathrm{s}, 5^{\circ} \mathrm{C}\left(\mathrm{T}_{\text {in }}\right)$ & $1.2-\log$ & Pina-Perez et al. (2009) \\
\hline L. innocua & 3.6\% Fat whole milk & $29 \mathrm{kV} / \mathrm{cm}, 250 \mu \mathrm{s},<45^{\circ} \mathrm{C}$ & $1.5-2-\log$ & Picart et al. (2002) \\
\hline $\begin{array}{l}\text { Mycobacterium } \\
\text { paratuberculosis }\end{array}$ & Milk & $30 \mathrm{kV} / \mathrm{cm}, 2500$ pulses, $\sim 50^{\circ} \mathrm{C}$ & 5.6-log, 5.9- $\log$ & Rowan et al. (2001) \\
\hline L. innocua & Whole milk & $40 \mathrm{kV} / \mathrm{cm}, 43.75 \mu \mathrm{s}, 68^{\circ} \mathrm{C}$ & $5.5-\log$ & $\begin{array}{l}\text { Guerrero-Beltrán et al. } \\
\qquad(2010)\end{array}$ \\
\hline S. aureus & Skim milk & $25 \mathrm{kV} / \mathrm{cm}, 100 \mu \mathrm{s}, \sim 50^{\circ} \mathrm{C}$ & $3-\log$ & $\begin{array}{c}\text { Sobrino-López \& } \\
\text { Martín-Belloso (2008) }\end{array}$ \\
\hline
\end{tabular}


functional, physical and chemical properties of various food items (Higuera-Barraza et al., 2016). The basic principle of US technology is based on the mechanical waves which are at a frequency, above the threshold level $(>16 \mathrm{kHz})$ of human hearing (Soria \& Villamiel, 2010). In liquid food samples, US causes periodic cycles of high and low pressure, as it conducts high intensity and frequency sound waves. During the high and low pressure cycle vacuum bubbles form and collapse violently (Zhao et al., 2014). Based on frequency range US technology can be divided into power ultrasound, high frequency ultrasound and diagnostic ultrasounds having ranges $20-100 \mathrm{kHz}$, $20 \mathrm{kHz}-2 \mathrm{MHz}$ and (>1 MHz), respectively. Based on application it can be divided broadly into high $\left(10-1000 \mathrm{~W} / \mathrm{cm}^{2}\right)$ and low $\left(<1 \mathrm{~W} / \mathrm{cm}^{2}\right)$ intensity sonication (Ojha et al., 2017).

\subsection{Applications in the dairy industry}

It has been used for homogenization of milk (Al-Hilphy et al., 2012), novel dairy products with unique physico-chemical and functional properties can be prepared alone with ultrasonication or in combination with different traditional homogenization techniques. (Jin et al., 2014) showed that there was increased crossflow ultrafiltration of skim milk by applying in situ ultrasonication. Inactivation of microbes through sonication is one of its applications in dairy industry. The effectiveness of microbial inactivation in retaliation to ultrasound depends on the type of targeted microorganisms. Gram-positive bacteria contain a thick and tightly adherent peptidoglycan cell wall layer which is resistant to sonication (Chemat et al., 2011). Gram-positive bacteria are generally more sensitive than Gram-negative microbes, while spores are more resistant than vegetative cells (Halpin et al., 2013).

\subsection{Effect on milk quality}

Use of ultrasound in food processing as compared to other novel technologies is limited. However, the utilization of ultrasound can have various advantages on milk processing such as removal of gases, homogenization of fat globules and increase in the activity of antioxidants (Evrendilek, 2014). Hence, continuous ultrasound flow treatment can be a favourable technology for the processing of milk. A total elimination of $E$. coli was observed due to ultrasound $(20 \mathrm{kHz}, 10 \mathrm{~min})$ application. After $6 \mathrm{~min}$, viable counts of $P$. fluorescens were reduced by $100 \%$ and L. monocytogenes were decreased by $99 \%$ after $10 \mathrm{~min}$
(Cameron et al., 2009). For both raw and pasteurized milk, protein or lactose contents were not changed with ultrasound, although it may induce rise in the fat concentration. Woefully, ultrasound does not cause the inactivation of lacto-peroxidase and alkaline-phosphate activities (Cameron et al., 2009). There is no change in the viscosity, but turbidity was reduced by the processing of homogenized pasteurized milk (skim) by sonication treatment $(20 \mathrm{kHz}$ at 20 and $41 \mathrm{~W})$ at different time intervals (up to $60 \mathrm{~min}$ ) under controlled conditions. The fat globules size, particles that are soluble and casein micelles change after 60 min of sonication with a change in energy generation. In milk whey proteins denaturation was observed, which forms aggregates of soluble whey proteins. During the first 30 minutes of sonication treatment, the interaction of these aggregates with casein micelles form micellar aggregates. When there was an increase in the times for sonication, some of the whey proteins were partially disrupted by these aggregates (Shanmugam et al., 2012). After sonication treatment, liquid egg and skim milk inoculation with Salmonella Typhimurium at 20 and $40^{\circ} \mathrm{C}$ for 30 mins cause reduction of 1 and $3-\log \mathrm{CFU} / \mathrm{mL}$ in counts of this bacteria, respectively (Wrigley \& Llorca, 1992). In the milk samples treated with frequency of $800 \mathrm{kHz}$ for $1 \mathrm{~min}$ with $8.4 \mathrm{~W} / \mathrm{cm}^{2}$ power intensity, coliform bacteria counts were reduced by $93 \%$.

\subsection{Effect on milk microbes}

Table 3 shows the influence of ultrasound treatment on milk microorganisms. Cameron et al. (2009) has reported the effect of sonication treatment $(20 \mathrm{kHz}$ for $10 \mathrm{~min}$ at $750 \mathrm{~W})$ in raw pasteurized milk that showed reduction to 5.34-log CFU/g in E. coli and 2.07-log CFU/g in L. monocytogenes but at $6 \mathrm{~min}$ with same ultrasonic conditions, it was reduced to 5.64-log CFU/g in P. fluorescens, which means microbes are more sensitive against ultrasound treatment. When raw whole cow's milk (4\% fat) was sonicated $\left(20 \mathrm{kHz}, 120 \mu \mathrm{m}\right.$ for $12 \mathrm{~min}$ at $\left.60^{\circ} \mathrm{C}\right)$, a $3.1-\log$ reduction in E. coli was observed (Herceg et al., 2012). After sonication treatment $\left(15.8 \pm 1.6 \mathrm{~mJ} / \mathrm{cm}^{2}, 18 \mathrm{sec}\right)$, L. monocytogenes was reduced to $10^{7} \mathrm{CFU} / \mathrm{mL}$ in goat milk (Matak et al., 2005). In another study, after ultrasound treatment $\left(20 \mathrm{kHz}\right.$ with $\left.60{ }^{\circ} \mathrm{C}\right)$ in UHT milk resulted in 0.3 min D value for L. monocytogenes (Earnshaw et al., 1995). García et al. (1989) has investigated that the inactivation of $B$. subtilis with a rate of 70 and $49 \%$ after sonicated milk treatment $\left(20 \mathrm{kHz}\right.$ with $150 \mathrm{~W}$ at $100{ }^{\circ} \mathrm{C}$ temperature), 2.5 to 3-log reduction of Salmonella Typhimurium

Table 3. Effect of ultrasound on different microorganism in milk.

\begin{tabular}{|c|c|c|c|c|}
\hline Microorganisms & Dairy Food & Treatment conditions & Reduction & References \\
\hline E. coli & $\begin{array}{l}\text { Raw whole } 4 \% \text { fat cow's } \\
\text { milk }\end{array}$ & $\begin{array}{c}20 \mathrm{kHz}, 120 \mu \mathrm{m}, 12 \mathrm{~min}, \\
60^{\circ} \mathrm{C}\end{array}$ & $3.1-\log$ & Herceg et al. (2012) \\
\hline E. coli & & $20 \mathrm{kHz}, 10 \mathrm{~min}, 750 \mathrm{~W}$ & 5.34-log CFU/g & \\
\hline P. fluorescens & Raw milk (pasteurization) & $20 \mathrm{kHz}, 6 \mathrm{~min}, 750 \mathrm{~W}$ & 5.64-log CFU/g & Cameron et al. (2009) \\
\hline L. monocytogenes & & $20 \mathrm{kHz}, 10 \mathrm{~min}, 750 \mathrm{~W}$ & 2.07-log CFU/g & \\
\hline L. monocytogenes & UHT milk & $\begin{array}{l}\text { Heat at } 60{ }^{\circ} \mathrm{C} \text { with } \\
\text { Sonication at } 20 \mathrm{kHz}\end{array}$ & $\mathrm{D}_{60 \& \mathrm{~S}}=0.3 \mathrm{~min}$ & Earnshaw et al. (1995) \\
\hline S. typhimurium & Skim milk & $\begin{array}{l}30 \mathrm{~min} \text { at } 50{ }^{\circ} \mathrm{C} \\
30 \mathrm{~min} \text { at } 40^{\circ} \mathrm{C}\end{array}$ & $\begin{array}{r}3-\log \\
2.5-\log \end{array}$ & Wrigley and Llorca (1992) \\
\hline E. coli K12DH5 A & UHT milk (pH 6.7) & $110 \mu \mathrm{m}, 60^{\circ} \mathrm{C}$ & $\mathrm{D}_{60 \& \mathrm{~S}}=23 \mathrm{~s}$ & Zenker et al. (2003) \\
\hline
\end{tabular}


in skim milk was attained after ultrasound treatment for $30 \mathrm{~min}$ at $40{ }^{\circ} \mathrm{C}$ and $50{ }^{\circ} \mathrm{C}$ (Wrigley \& Llorca, 1992).

\section{Ultraviolet irradiation}

UV radiation (spectrum ranges from 100-400 nm) technology has been used for decades (60 years) primarily for the disinfection of water, surfaces and air (Guneser \& Karagul Yuceer, 2012). In food industry, it is being effectively used for the microbial decontamination of packaging materials and surfaces. The major drawback of using this technology is that, it has low penetration power and suspended solids reduce its effectiveness in liquid samples (as $254 \mathrm{~nm}$ UV radiation suffers 30\% loss; below $5 \mathrm{~cm}$ surface, in intensity in 10\% sucrose solution (Falguera et al., 2011). In the electromagnetic spectrum, UV light has 3 regions UV-A, UV-B and UV-C spectrum ranges from 315-400 nm, 280-315 nm, 200-280 nm respectively, provided that the UV-C region have the germicidal properties. UV-C radiation act on both pathogenic and spoilage causing microorganisms (viruses and protozoa) by damaging the DNA which eventually prevents the transcription and replication process, resultantly causing cell death (Choudhary \& Bandla, 2012). The effect of UV-C radiation depends on the microbial load, flow and optical properties of the product, wavelength, power, geometric configuration of the device, radiation path length and physical arrangement of UV source (Guneser \& Karagul Yuceer, 2012).

\subsection{Application in the dairy industry}

Milk turbidity is a major challenge presented by UV light treatment when used for pasteurization. Turbidity in milk decreases microbial inactivation due to lower UV light penetration in turbid milk. Suspended and colloidal solids present at high level in milk make it turbid that causes the opaqueness of milk. In modern UV reactors, there are two strategies that have been used to increase the UV light penetration into milk based on the fluid flow, which opened the ways in food and dairy industries for pasteurization using application of this technology. The first approach employs laminar flow of milk or fluid by very thin film formation on a UV irradiated surface which results in complete penetration of light through the milk. Second approach employs the use of turbulent flow of milk by bringing all liquid parts into close proximity of UV light exposed surfaces which decreases the required path length and results in good UV light penetration in milk (Datta et al., 2015). Few studies regarding effects of UV processing on whole milk quality demonstrated that there was no notable change in the viscosity, colour, $\mathrm{pH}$, soluble solid contents and viscosity of milk. The $\mathrm{pH}$ range of milk treated under UV was 6.66 to 6.70 , viscosity was on average of $2.00 \pm 0.01$ ( $\mathrm{m} \mathrm{Pa} \mathrm{s})$, the colour change $\Delta \mathrm{E}^{\star}$ was in range of $0-0.5$ and contents of soluble solid was $12.78 \pm 0.10(\% \mathrm{~g} / \mathrm{g})$ when pasteurized whole milk was treated with UV having dose of $10 \mathrm{~mJ} / \mathrm{cm} 2$ (12 to $235 \mathrm{~min}$ ) (Orlowska et al., 2013).

\subsection{Effect on microbes}

Table 4 represents the UV irradiation effect on microorganisms present in milk. The raw cow milk treated with UV dose (1.5 J m/L using 1 and 2 pure version of reactors) resulted in a 3-log reduction of natural microflora (Reinemann et al., 2006). UV reactors (dean flow) efficiency and their effects on inactivation of $B$. cereus endospores and E. coli W1485 in raw cow milk, commercially processed skim milk and in soymilk has been studied (Bandla et al., 2012).

By using a reactor (dean flow) with a diameter of $1.6 \mathrm{~mm}$ having UV dose $(0.05 \mathrm{~J} \mathrm{~m} / \mathrm{L})$, reduction of E. coli W 1485 (>7-log) in skimmed milk and soymilk (>5-log reduction) was observed. The 4-log reduction of $E$. coli W 1485 was resulted by using a same UV dose and reactor in raw cow milk. For raw cow milk because of less transmission of UV, a higher dose of UV was recommended than soymilk and skimmed milk. For treatment of UV, milk and dairy products pose a challenge due to containment of high amount of spoilage and pathogenic microorganisms as compared to fruit juices. In sweet, acid and brine whey, the total bacterial count reduced to 7-log, showing the possible use of treatment with UV in brine and whey for processing of dairy products (Gupta, 2011).

According to Matak et al. (2005), UV radiation was employed for reducing the L. monocytogenes population. Population of Listeria was reduced by 5-log units in raw goat milk when UV was applied (UV dose $158 \pm 16 \mathrm{Jm}^{2}$ ). In whey, there was a reduction of the total bacterial viable count of 3.5-log when turbulent reactor was used while UV intensity was at $450 \mathrm{~W} / \mathrm{m}^{2}$ (Simmons et al., 2012).

\section{Plasma and low plasma treatment}

Plasma (quasi-neutral gas) technology (PT), is one of the newly developed technology, having various applications in food industry. PT improves the quality and ensures the safety of the food product from both pathogenic and spoilage causing microorganisms, without affecting the functional, sensory and nutritional profile (Mir et al., 2016). PT is based on a simple physical principle, the gas is fed by additional energy by means of electrical discharge, which resultantly turns it into energy rich

Table 4. Effect of UV irradiation on different microbes in milk.

\begin{tabular}{|c|c|c|c|c|}
\hline Microorganisms & Dairy Food & Treatment conditions & Reduction & References \\
\hline \multirow[t]{2}{*}{ L. monocytogenes } & Goat milk & $15.8 \pm 1.6 \mathrm{~mJ} / \mathrm{cm}^{2}, 18 \mathrm{~s}$ & $5-\log$ & Matak et al. (2005) \\
\hline & Skim milk (0\%fat) & & $2.29-\log$ & \\
\hline \multirow[t]{3}{*}{ E. coli ATCC 25922} & Reduced fat milk (2\%fat) & $5.8 \mathrm{~mJ} / \mathrm{cm}^{2}$ for $1.5 \mathrm{sec}, 4^{\circ} \mathrm{C}$ & $1.82-\log$ & Bandla (2010) \\
\hline & Whole milk (3.25\%fat) & & $0.73-\log$ & \\
\hline & Soya milk & & $>5-\log$ & \\
\hline E. coli & Raw cow milk & Dean flow reactor $(1.6 \mathrm{~mm}), \mu \mathrm{v}$ dose $(0.05 \mathrm{~J} / \mathrm{mL})$ & $4-\log$ & Bandla et al. (2012) \\
\hline
\end{tabular}


plasma (fourth state of matter) state. Plasma is completely or partially ionized state consisting of free electrons and radicals, intermediate highly reactive species, negatively and positively charged ions, UV photons, molecules and atoms with a neutral charge (Sarangapani et al., 2015). Low temperature property and higher efficiency in microbial inactivation are the most attractive features of PT (Guo et al., 2015). Moreover, it is important to note that, PT induce modifications only on the surface of the food as plasma reactive species do not have penetrating power (Fernández \& Thompson, 2012). In food industry, PT is mostly used for enzyme inactivation, waste water treatment, food packaging modification, toxic removal and food decontamination (Pankaj et al., 2018).

\subsection{Application in the dairy industry}

Regarding microorganism inactivation, there are few studies executed on cold plasma treatment in milk and dairy industries, but it is mostly used in chemistry, polymer and medical industries.

\subsection{Effect on microbes}

Table 5 and Table 6 show the summary of microbial inactivation by Plasma technology in milk. Ruan (2007) showed a 2.95, 2.74, 0.18-log reduction of Salmonella (5 strain-mixture), L. monocytogenes (5 strain-mixture) and B. cereus (3 strain-mixture) respectively when skim milk was subjected to $35-40 \mathrm{kV}$ with an exit temperature $<60^{\circ} \mathrm{C}$, and single pass concentrated high-intensity electric field (CHIEF). In skim milk, when strains of Salmonella, E. coli and L. monocytogenes was subjected to double pass CHIEF with $35-40 \mathrm{kV}$ and an exit temperature of $<60^{\circ} \mathrm{C}$ caused a 5.55 , 4.36 and 4.73-log reduction, respectively. E. coli ATCC 25922 was reduced to $3.40-\log$ in semi-skimmed milk, 3.63-log in whole milk and 3.34-log in skimmed milk when it was subjected to low-temperature plasma treatment (AC power supply $9 \mathrm{kV}$, $20 \mathrm{~min},<35^{\circ} \mathrm{C}$ ) (Korachi \& Aslan, 2011; Korachi et al., 2010). The inactivation rate of plasma on E. coli, Salmonella typhimurium and $S$. aureus in whole, semi-skimmed and skimmed milk that stored at $4{ }^{\circ} \mathrm{C}$ for 42 days were conducted, and after plasma treatment $(20 \mathrm{kV})$, the counts of E. coli, S. typhimurium, and S. aureus was reduced to $3.63,2.00$ and $2.62-\log \mathrm{CFU} / \mathrm{mL}$, respectively. There was no remarkable change in colour and $\mathrm{pH}$ of samples of milk. After 1-week examination, there were no viable cells detected in whole milk and the samples remained stable after six weeks of storage (Evrendilek, 2014).

\section{Membrane filtration}

Membrane filtration (MF) technology is basically a separation process which particularly employs semi-permeable membranes to concentrate or fractionate liquids into two diverse compositions, generally by allowing some selective compounds to pass and preventing others. The retained liquid is referred as retentate and passed out liquid is known as permeate. The effectivity of membranes is mainly directed by the hydrostatic pressure (or transmembrane pressure) through the membrane and concentration gradient of liquids. Dairy industry has been applying MF technology since 1960 (Kumar et al., 2013). In food industry, primarily in dairy industry, MF processes (for example nanofiltration or ultrafiltration) are used for higher outputs of concentration and separation of proteins (Leeb et al., 2014). As a non-thermal technology it reduces the total viable count of bacteria along with their spores thus prolonging shelf life without damaging the nutritional and sensory profile of dairy products (Kumar et al., 2013).

\subsection{Application in the dairy industry}

Khanal (2014) has described the uses of MF in the dairy industry for casein concentration (milk fractionation), fat separation, bacterial removal and spore removal. It can be used to clarify the food material and separate the suspended particles of 0.10 to $5 \mu \mathrm{m}$ range in the food industry. MF is used to enhance the milk shelf-life by reducing the microbial load and remove spores from the milk while keeping the organoleptic quality as before (Khanal, 2014). The membranes made of cellulose acetate are among the most popular in dairy industry because of their low cost and low fouling characters. The membrane processing was first used in the dairy industry for separating milk components in the late 1960s, and now is widely used for whey and cheese processing (Gésan-Guiziou, 2010), but Fernández García et al. (2013) have confirmed that

Table 5. Effect of plasma technology on different microbes in milk.

\begin{tabular}{cccc}
\hline Microorganisms & Dairy Food & Treatment conditions & Reduction \\
\hline E. coli O157:H7 ATCC43895 & Milk & & $\geq 3.94-\log$ \\
Salmonella (5 strain mixture) & & $35-40 \mathrm{kV}$, exit temperature $<60^{\circ} \mathrm{C}$, single pass CHIEF & $2.95-\log$ \\
L. monocytogenes (5 strain mixture) & & $2.74-\log$ \\
B. cereus (3 strain mixture) & Skim milk & & $0.18-\log$ \\
E. coli O157:H7 (5 strain mixture) & & $35-40 \mathrm{kV}$, exit temperature $<60^{\circ} \mathrm{C}$, double pass CHIEF & $4.36-\log$ \\
Salmonella (5 strain mixture) & & & $5.55-\log$ \\
L. monocytogenes (5 strain mixture) & & & $4.73-\log$ \\
\hline
\end{tabular}

Table 6. Effect of low temperature plasma treatment on different microbes in milk.

\begin{tabular}{ccccc}
\hline Microorganisms & Dairy Food & Treatment conditions & Reduction & References \\
\hline & Whole milk & & $3.63-\log$ & Korachi et al. (2010); Korachi \& \\
E. coli ATCC 25922 & Semi-skimmed milk & $9 \mathrm{kV}$ of AC power supply, 20 min, temp below $35^{\circ} \mathrm{C}$ & $3.40-\log$ & Aslan, (2011) \\
& Skimmed milk & & $3.34-\log$ & \\
\hline
\end{tabular}


that membrane processing was first used to separate cream and skim milk using polymeric filters with $0.2-10 \mu \mathrm{m}$ pore sizes while $2 \mu \mathrm{m}$ ceramic membranes were successfully used to obtain the skim milk virtually free from fat.

\subsection{Effect on microbes}

Table 7 shows the summary of microbial inactivation by membrane microfiltration in milk. Rodríguez-González et al. (2011) counted a 2.1-log reduction in mesophilic micro-organisms in skim milk, using cross-flow MF of $1.4 \mu \mathrm{m}$ pore size. Maubois (2002) has reported a reduction of $>3.5-\log$ in the vegetative cells of skim milk after MF processing $\left(55^{\circ} \mathrm{C}, 1.4 \mu \mathrm{m}\right.$ pore size). The MF treated milk was free from somatic cells, and the spore reduction was $>4.5-\log$. Pafylias et al. (1996) have investigated the efficiency to remove the bacteria from inoculated reconstituted skim milk through MF ceramic membrane $(1.4 \mu \mathrm{m}$ pore sized) while average of $4.5-\log$ reduction in bacterial count was reported. They also concluded that a reduction in bacterial count substantially in skim milk can be attained without any significant changes in the milk composition.

Fritsch \& Moraru (2008) investigated the efficiency of MF to remove the microorganisms, spores and somatic cells from skim milk at cold temperatures. They were unable to detect any bacteria in permeate from skim milk having an initial count of 5.25 and $2.15-\log \mathrm{CFU} / \mathrm{mL}$ of vegetative bacteria and spores, respectively following the application of MF treatment (pore size of $1.4 \mu \mathrm{m}$ at $6^{\circ} \mathrm{C}$ ) and somatic cell count was reduced to 3.0-log. (Gosch et al., 2014) used 0.8 and $1.4 \mu \mathrm{m} \mathrm{MF}$ (tubular ceramic ISOFLUX ${ }^{\circledR}$ membrane) to process colostrum and skim milk. The microbial removal with a $0.8 \mu \mathrm{m}$ MF membrane was more efficient than $>5.4-\log$ reduction in total viable count, while $>3.5 \mathrm{log}$ reduction in the count using a membrane having pore size of $1.4 \mu \mathrm{m}$. On the other hand, both types of MF reduced the total viable counts to $>2.3 \log \mathrm{CFU} / \mathrm{mL}$ in skim milk. They also used 0.14 and $0.2 \mu \mathrm{m} \mathrm{MF}$ and reported that permeate from both of these membranes were almost free $(<1.0-\log \mathrm{CFU} / \mathrm{mL})$ from microorganisms. To check the efficiency of membrane filtration in removing the bacteria and spores from milk, $1.4 \mu \mathrm{m}$ ceramic membrane MF treatment was applied (Caplan \& Barbano, 2013). The skim milk processed through $1.4 \mu \mathrm{m} \mathrm{MF}$ at $51^{\circ} \mathrm{C}$, reduced the bacterial count to 4.13-log cycles while the spore count was found $<1.0-\log$. (Daufin et al., 2001) reported a microbial reduction of 2.1 to $3.1-\log \mathrm{CFU} / \mathrm{mL}$ when milk was passed through $1.4 \mu \mathrm{m}$ MF, depending on initial count and morphology of the bacteria, while (Gésan-Guiziou, 2010) counted a 2-3-log reduction in using a ceramic membrane with $1.4 \mu \mathrm{m}$ (pore size). However, the efficiency of Sterilox ${ }^{\circledR}$ membranes (Pall-Exekia Company) is much better due to narrow pore distribution size and can reduce the microbial load by 5 to 6 -log and 3 to $4-\log \mathrm{CFU} / \mathrm{mL}$ using 0.8 and $1.4 \mu \mathrm{m} \mathrm{MF}$, respectively. Elwell \& Barbano (2006) investigated the quality and storage stability of skim milk following MF using ceramic membranes having pore size of $1.4 \mu \mathrm{m}$ and they found 3.79-log reduction in the bacterial count and reported that spore count was reduced to an undetectable level from initial counts of 2-log CFU $/ \mathrm{mL}$ in raw milk. Another study reported $>3.5$-log reductions of bacterial count, and retention of all somatic cells in skim milk, when filtered through a pore size of $1.4 \mu \mathrm{m}$ membrane at $50^{\circ} \mathrm{C}$. On comparing the results with $0.5 \mu \mathrm{m}$ membrane processing, the bacterial reduction was increased to 2-3-log when the smaller pore size membrane was used (Saboyainsta \& Maubois, 2000). Trouvé et al. (1991) observed $>4.5$-log reductions of spore-forming bacteria when skim milk was treated with a $1.4 \mu \mathrm{m}$ membrane. In another study, Brans et al. (2004) investigated the use of a $0.5 \mu \mathrm{m}$ micro-sieve, an advanced type of membrane filter. This type of membrane has a narrow pore size distribution and can work at a low trans-membrane pressure and attained a 6.6-log reduction in B. subtilis that was inoculated in SMUF.

\section{Combined treatments}

Table 8 illustrate the effect of combined nonthermal treatments on inactivation of milk microbes. It has been proved that combination of two different nonthermal techniques has shown the best results than single treatment (alone) for the reduction of microorganisms. When a combination of HPP and heat was applied on UHT milk (400 MPA, $50{ }^{\circ} \mathrm{C}$ for $15 \mathrm{~min}$ ) it resulted in 5.0- $\log$ reduction of E. coli O157:H7 (Patterson \& Kilpatrick, 1998). At 20 to $30^{\circ} \mathrm{C}$, the bacterial vegetative cells showed the greatest resistance to HPP, while at lower and higher temperature microbes were much sensitive to HPP. The resistance showed by bacterial vegetative cells to HPP decreases even at non-lethal temperatures when pressure is used in combination with heat. This combination allows the inactivation ( $>6$-log cycles) of pathogenic and spoilage microorganisms substantially at lower pressures or shorter times than that required at room temperature. In UHT milk the L. monocytogenes did not inactivate at $200 \mathrm{MPa}$ up to $45^{\circ} \mathrm{C}$, while 6-log reduction was obtained in cell count after $200 \mathrm{MPa}, 55^{\circ} \mathrm{C}$ and $15 \mathrm{~min}$ (Simpson \& Gilmour, 1997). The resistance showed by different strains (E. coli O157:H7, Salmonella species, L. monocytogenes and S. aureus) at $25^{\circ} \mathrm{C}$ with

Table 7. Effect of membrane microfiltration (MF) treatment on different microbes in milk.

\begin{tabular}{|c|c|c|c|c|}
\hline Microorganisms & Dairy Food & Treatment conditions & Reduction & References \\
\hline \multirow{3}{*}{ Total bacterial load } & \multirow{3}{*}{$\begin{array}{c}\text { Skim milk } \\
\text { Reconstituted skim milk }\end{array}$} & \multirow{2}{*}{ MF-1.4 $\mu \mathrm{m}$, ceramic membrane, $\mathrm{Tp}=50^{\circ} \mathrm{C}$} & $5.18-\log$ & Awad et al. (2010) \\
\hline & & & $4.5-\log$ & Pafylias et al. (1996) \\
\hline & & MF-1.4 $\mu \mathrm{m}$, ceramic membrane, $\mathrm{Tp}=55^{\circ} \mathrm{C}$ & $>3.5-\log$ & Maubois (2002) \\
\hline Spores & Skim milk & MF- $1.4 \mu \mathrm{m}$, ceramic membrane, $\mathrm{Tp}=55^{\circ} \mathrm{C}$ & $>4.5-\log$ & Maubois (2002) \\
\hline Bacillus cereus spores & & MF-1.4 $\mu \mathrm{m}$, ceramic membrane & $3.5-\log$ & Olesen \& Jensen (1989) \\
\hline
\end{tabular}


Table 8. Effect of combined treatments on different microbes in milk.

\begin{tabular}{|c|c|c|c|c|c|}
\hline Treatment & Microorganisms & Dairy food & Treatment conditions & Reduction & References \\
\hline \multirow[b]{2}{*}{ Thermosonication } & S. aureus & Milk 4\% fat & $20 \mathrm{kHz}, 4,8 \mathrm{~min}, 120 \mu \mathrm{m}, 60^{\circ} \mathrm{C}$ & $1-\log \mathrm{CFU} / \mathrm{g}$ & Herceg et al. (2012) \\
\hline & L. innocua & Raw and whole cow's milk & $\begin{array}{c}63 \pm 0.5^{\circ} \mathrm{C}, 24 \mathrm{kHz}, 129 \mathrm{~mW} / \mathrm{mL} \\
400 \mathrm{~W}, 120 \mathrm{~mm}, 10 \mathrm{~min}\end{array}$ & $5-\log \mathrm{CFU} / \mathrm{mL}$ & $\begin{array}{l}\text { Bermúdez-Aguirre et al. } \\
\text { (2011) }\end{array}$ \\
\hline \multirow[t]{2}{*}{$\begin{array}{l}\text { PEF and electrically } \\
\text { induced heat }\end{array}$} & & Pasteurized whole milk & $40 \mathrm{kV} / \mathrm{cm}, 15$ pulses, $23^{\circ} \mathrm{C}\left(\mathrm{T}_{\mathrm{i}}\right), 10 \mathrm{~s}$ & $5.5-\log$ & $\begin{array}{l}\text { Guerrero-Beltrán et al. } \\
\text { (2010) }\end{array}$ \\
\hline & L. іппосиа & Raw whole milk & $120 \mu \mathrm{m}, 2.85 \mathrm{~W} / \mathrm{cm}^{2} / 63 \pm 0.5^{\circ} \mathrm{C} / 30 \mathrm{~min}$ & 3.58- $\log$ & $\begin{array}{l}\text { Earnshaw, Appleyard } \\
\text { and Hurst, (1995) }\end{array}$ \\
\hline \multirow{3}{*}{ Thermosonication } & B. subtilis spores & Whole milk & US: $20 \mathrm{kHz}, 150 \mathrm{~W}, \mathrm{~V}=30 \mathrm{~mL}, 100^{\circ} \mathrm{C}$ & $\mathrm{D}_{\mathrm{TUS}}=1.6$ & \multirow[b]{2}{*}{ García et al. (1989) } \\
\hline & L. monocytogenes & UHT milk & US: $20 \mathrm{kHz}, 150 \mathrm{~W}, \mathrm{~V}=30 \mathrm{~mL}, 60^{\circ} \mathrm{C}$ & $\mathrm{D}_{\mathrm{TUS}}=0.3$ & \\
\hline & E. coli & UHT milk (pH 6.7) & US: $20 \mathrm{kHz}, 110 \mu \mathrm{m}, \mathrm{V}=10 \mathrm{~mL}, 60^{\circ} \mathrm{C}$ & $\mathrm{D}_{\mathrm{TUS}}=0.4$ & Zenker et al. (2003) \\
\hline HPP and Heat & L. monocytogenes & UHT milk & $375 \mathrm{MPA} / 15 \mathrm{~min} / 35^{\circ} \mathrm{C}$ & $3.5-\log$ & $\begin{array}{c}\text { Simpson \& Gilmour } \\
(1997)\end{array}$ \\
\hline
\end{tabular}

$345 \mathrm{MPa}$, but at $50{ }^{\circ} \mathrm{C}$ these differences were greatly decreased (Alpas et al., 1999). In general, the kinetics of inactivation of most vegetative cells by HPP at low temperatures shows an initial exponential rate, followed by pronounced tailing (Smelt, 1998). This trail disappears when HPP is combined with heat (Kalchayanand et al., 1998).

Herceg et al. (2012) used combination of heat with ultrasound and showed 1-log reduction of $S$. aureus when milk having $4 \%$ fat was subjected to $20 \mathrm{kHz}$ frequency for $4-8 \mathrm{~min}$ and $120 \mu \mathrm{m}$ with a temperature of $60^{\circ} \mathrm{C}$ and $E$. coli also reduced by $1-\log$ reduction when milk was subjected to thermosonication $\left(20 \mathrm{kHz}, 2.78 \mathrm{~min}\right.$ and $\left.60^{\circ} \mathrm{C}\right)$. Ultrasound treatment with lethal or sub-lethal temperatures (ultrasound-assisted thermal processing) has numerous benefits and proved to be an effective technique in prolonging the shelf life of foods. It can take a product to the better-quality with enhancements in the appearance, taste and texture than conventionally treated by heat, which reduces the cost and energy requirements. During sonication, sensitivity of microbes towards temperature could be the factor in addition to the effect on the phenomenon of cavitation. The changes in pressure happen during cavitation, which are responsible for the inactivation effect, then temperature rise, and disruption enhances the membrane fluidity i.e. weakening the intermolecular forces (Russell, 2002). García et al. (1989) first introduced that bacterial cells become highly sensitive to heat treatment, if they have undergone sonication treatment. In UHT milk, S. aureus was reduced to $6.0-\log$ after $500 \mathrm{MPa}, 5 \mathrm{~min}$ at $50^{\circ} \mathrm{C}$, while $<1.0-\log$ in numbers was achieved either with a single treatment. It has been reported that to get better spore inactivation, pressure can also be used with temperature. Destruction of spores (B. subtilis and $C$. sporogenes) was increased by temperature elevation (Stewart et al., 2000). HPP can cause the effective inactivation of spores (B. stearothermophilus) at elevated temperatures (Ananta et al., 2001). A single sonication treatment had no effect, but applying thermosonication in glycerol, 63 to $73 \%$ (<1-log cycle CFU/mL) population of spores was reduced from 40 to $79 \%$ in milk. The reduction in water (distilled) ranges from 70 to $99.9 \%$ (3-log cycle CFU/mL). As the treatment temperature reached to $100^{\circ} \mathrm{C}$, the thermosonication effect was dramatically diminished. For the maximum spore's inactivation, the optimum temperature was $70{ }^{\circ} \mathrm{C}$ under the experimental conditions.

\section{Cost effectiveness of non-thermal technologies}

The capital and operating cost of HPP equipment will continue to decrease according to the demand of equipment (Campus, 2010). So, the average processing cost (depending upon the processing conditions) of HPP is US\$0.05-0.5 per litre or kilogram of different food items, which is lower than the thermal processing cost. HPP technology is suitable and can be cost effectively used for premium products (Bermúdez-Aguirre \& Barbosa-Cánovas, 2010). Töpfl (2006) reported that operation cost of PEF was in the span of US\$ 0.011-0.022 per litre for the preservation of liquid media and this was 10 -fold greater than needed cost for the conventional thermal processing. PEF can effectively accelerate the drying process in food industry, as compared to conventional drying that employ elevated heat by precisely controlling the process temperature, leading to decrease in energy cost and gas consumption (Pereira \& Vicente, 2010). US technology can be cost effectively used for extraction processes and rapid crystallization of food material, and provide benefits such as less processing time, increased final yield, greater penetration power and reduced cost (Chandrapala et al., 2013). Current limitations, for the application of non-thermal technologies, including high investment cost, lack of regulatory support and full control of variables have been delaying the broader application of these technologies in the industrial sector (Pereira \& Vicente, 2010).

\section{Conclusions}

Novel nonthermal technologies have the capability to inactivate the microbes present in milk and milk products. These techniques facilitate less destruction in nutritional contents of milk as compared to thermal techniques and enhance the shelf life as well. Major nonthermal approaches for decontamination of milk and milk products include HPP, PEF, sonication, thermosonication and 
various other methods. Combined effects of these technologies appear to be the most successful in processing of milk. This could inactivate the pathogenic and spoilage microbes and minimise the nutritional quality deterioration in milk and milk products. Hence, these techniques may operate in the dairy and food industries in large scale in future processing operations.

\section{Acknowledgements}

The authors are grateful to the Higher Education Commission (HEC), National Research Program for Universities (NRPU-7366).

\section{References}

Aadil, R. M., Khalil, A. A., Rehman, A., Khalid, A., Inam-ur-Raheem, M., Karim, A., Gill, A. A., Abid, M., \& Afraz, M. T. (2020). Assessing the impact of ultra-sonication and thermo-ultrasound on antioxidant indices and polyphenolic profile of apple-grape juice blend. Journal of Food Processing and Preservation, 14406(5). http://dx.doi. org/10.1111/jfpp.14406.

Aadil, R. M., Zeng, X. A., Han, Z., \& Sun, D. W. (2013). Effects of ultrasound treatments on quality of grapefruit juice. Food Chemistry, 141(3), 3201-3206. http://dx.doi.org/10.1016/j.foodchem.2013.06.008. PMid:23871078.

Aadil, R. M., Zeng, X. A., Han, Z., Sahar, A., Khalil, A. A., Rahman, U., Khan, M., \& Mehmood, T. (2018). Combined effects of pulsed electric field (PEF) and ultrasound (US) on bioactive compounds and microbial quality of grapefruit juice. Journal of Food Processing and Preservation, 42(2), e13507. http://dx.doi.org/10.1111/jfpp.13507.

Aadil, R. M., Zeng, X. A., Zhang, Z. H., Wang, M. S., Han, Z., Jing, H., \& Jabbar, S. (2015a). Thermosonication: a potential technique that influences the quality of grapefruit juice. International Journal of Food Science \& Technology, 50(5), 1275-1282. http://dx.doi. org/10.1111/ijfs.12766.

Aadil, R. M., Zeng, X. A., Wang, M. S., Liu, Z. W., Han, Z., Zhang, Z. H., Hong, J., \& Jabbar, S. (2015b). A potential of ultrasound on minerals, micro-organisms, phenolic compounds and colouring pigments of grapefruit juice. International Journal of Food Science \& Technology, 50(5), 1144-1150. http://dx.doi.org/10.1111/ijfs.12767.

Aadil, R. M., Zeng, X. A., Ali, A., Zeng, F., Farooq, M. A., Han, Z., Khalid, S., \& Jabbar, S. (2015c). Influence of different pulsed electric field strengths on the quality of the grapefruit juice. International Journal of Food Science \& Technology, 50(10), 2290-2296. http:// dx.doi.org/10.1111/ijfs.12891.

Aadil, R. M., Zeng, X. A., Sun, D. W., Wang, M. S., Liu, Z. W., \& Zhang, Z. H. (2015d). Combined effects of sonication and pulsed electric field on selected quality parameters of grapefruit juice. Lebensmittel-Wissenschaft + Technologie, 62(1), 890-893. http:// dx.doi.org/10.1016/j.lwt.2014.10.025.

Ahmad, T., Aadil, R. M., Ahmed, H., Rahman, U. U., Soares, B. C. V., Souza, S. L. Q., Pimentel, T. C., Scudino, H., Guimarães, J. T., Esmerino, E. A., Freitas, M. Q., Almada, R. B., Vendramel, S. M. R., Silva, M. C., \& Cruz, A. G. (2019a). Treatment and utilization of dairy industrial waste: a review. Trends in Food Science \& Technology, 88, 361-372. http://dx.doi.org/10.1016/j.tifs.2019.04.003.

Ahmad, T., Butt, M. Z., Aadil, R. M., Inam-ur-Raheem, M., Abdullah, Bekhit, A. E.-D., Guimarães, J. T., Balthazar, C. F., Rocha, R. S., Esmerino, E. A., Freitas, M. Q., Silva, M. C., Sameen, A., \& Cruz, A. G. (2019b). Impact of different nonthermal technologies on the reduction of different milk enzymes. International Journal of Dairy Technology, 72(4), 481-495. http://dx.doi.org/10.1111/1471-0307.12622.
Alegbeleye, O. O., Guimarães, J. T., Cruz, A. G., \& Sant’Ana, A. S. (2018). Hazards of a 'healthy'trend? An appraisal of the risks of raw milk consumption and the potential of novel treatment technologies to serve as alternatives to pasteurization. Trends in Food Science \& Technology, 82, 148-166. http://dx.doi.org/10.1016/j.tifs.2018.10.007.

Al-Hilphy, A. R. S., Niamah, A. K., \& Al-Timimi, A. B. (2012). Effect of ultrasonic treatment on buffalo milk homogenization and numbers of bacteria. World Journal of Dairy Food Sciences, 7(2), 185-189.

Alirezalu, K., Munekata, P. E. S., Parniakov, O., Barba, F. J., Witt, J., Toepfl, S., Wiktor, A., \& Lorenzo, J. M. (2020). Pulsed electric field and mild heating for milk processing: a review on recent advances. Journal of the Science of Food and Agriculture, 100(1), 16-24. http:// dx.doi.org/10.1002/jsfa.9942. PMid:31328265.

Alpas, H., Kalchayanand, N., Bozoglu, F., Sikes, A., Dunne, C., \& Ray, B. (1999). Variation in resistance to hydrostatic pressure among strains of food-borne pathogens. Applied and Environmental Microbiology, 65(9), 4248-4251. http://dx.doi.org/10.1128/AEM.65.9.42484251.1999. PMid:10473446.

Amador Espejo, G. G., Hernández-Herrero, M. M., Juan, B., \& Trujillo, A. J. (2014). Inactivation of Bacillus spores inoculated in milk by ultra high pressure homogenization. Food Microbiology, 44, 204210. http://dx.doi.org/10.1016/j.fm.2014.06.010. PMid:25084664.

Amaral, G. V., Silva, E. K., Costa, A. L. R., Alvarenga, V. O., Cavalcanti, R. N., Esmerino, E. A., Guimarães, J. T., Freitas, M. Q., Sant'Ana, A. S., Cunha, R. L., Moraes, J., Silva, M. C., Meireles, M. A. A., \& Cruz, A. G. (2018). Whey-grape juice drink processed by supercritical carbon dioxide technology: physical properties and sensory acceptance. Lebensmittel-Wissenschaft + Technologie, 92, 80-86. http://dx.doi. org/10.1016/j.lwt.2018.02.005.

Ananta, E., Heinz, V., Schlüter, O., \& Knorr, D. (2001). Kinetic studies on high-pressure inactivation of Bacillus stearothermophilus spores suspended in food matrices. Innovative Food Science \& Emerging Technologies, 2(4), 261-272. http://dx.doi.org/10.1016/ S1466-8564(01)00046-7.

Anema, S. G., Lowe, E. K., \& Stockmann, R. (2005). Particle size changes and casein solubilisation in high-pressure-treated skim milk. Food Hydrocolloids, 19(2), 257-267. http://dx.doi.org/10.1016/j. foodhyd.2004.04.025.

Awad, S., Ahmed, N., \& El Soda, M. (2010). Influence of microfiltration and adjunct culture on quality of domiati cheese. Journal of Dairy Science, 93(5), 1807-1814.

Bandla, S. (2010). Design of Dean flow ultraviolet (UV) reactors and testing their efficacy for inactivation of Escherichia coli $W$ and Bacillus cereus spores in milk. Carbondale: Southern Illinois University.

Bandla, S., Choudhary, R., Watson, D. G., \& Haddock, J. (2012). UV-C treatment of soymilk in coiled tube UV reactors for inactivation of Escherichia coli W1485 and Bacillus cereus endospores. LebensmittelWissenschaft + Technologie, 46(1), 71-76. http://dx.doi.org/10.1016/j. lwt.2011.10.024.

Barba, F. J., Koubaa, M., Prado-Silva, L., Orlien, V., \& Sant'Ana, A. S.. (2017). Mild processing applied to the inactivation of the main foodborne bacterial pathogens: a review. Trends in Food Science \& Technology, 66, 20-35. http://dx.doi.org/10.1016/j.tifs.2017.05.011.

Bendicho, S., Espachs, A., Arantegui, J., \& Martín, O. (2002). Effect of high intensity pulsed electric fields and heat treatments on vitamins of milk. The Journal of Dairy Research, 69(1), 113-123. http://dx.doi. org/10.1017/S0022029901005258. PMid:12047102.

Bermúdez-Aguirre, D., \& Barbosa-Cánovas, G. V. (2010). An update on high hydrostatic pressure, from the laboratory to industrial applications. Food Engineering Reviews, 3(1), 44-61. http://dx.doi. org/10.1007/s12393-010-9030-4. 
Bermúdez-Aguirre, D., Mawson, R., \& Barbosa-Canovas, G. B. (2011). Study of possible mechanisms of inactivation of Listaeria Innocua in thermo-sonicated milk using scanning electron microscopy and trasmission electron microscopy. Journal of Food Processing and Preservation, 35, 767-777.

Black, E. P., Stewart, C. M., \& Hoover, D. G. (2011). Microbiological aspects of high pressure food processing. Nonthermal Processing Technologies for Food, 5, 51-71. http://dx.doi.org/10.1002/9780470958360.ch5.

Brans, G., Schroën, C., Van der Sman, R., \& Boom, R. (2004). Membrane fractionation of milk: state of the art and challenges. Journal of Membrane Science, 243(1-2), 263-272. http://dx.doi.org/10.1016/j. memsci.2004.06.029.

Briñez, W. J., Roig-Sagués, A. X., Herrero, M. M. H., \& López, B. G. (2007). Inactivation of Staphylococcus ssp. Strains in whole milk and orange juice using ultra high pressure homogenization at inlet temperatures of 6 and $20^{\circ} \mathrm{C}$. Food Control, 18, 1282-1288.

Cameron, M., McMaster, L. D., \& Britz, T. J. (2009). Impact of ultrasound on dairy spoilage microbes and milk components. Dairy Science \& Technology, 89(1), 83-98. http://dx.doi.org/10.1051/dst/2008037.

Campus, M. (2010). High pressure processing of meat, meat products and seafood. Food Engineering Reviews, 2(4), 256-273. http://dx.doi. org/10.1007/s12393-010-9028-y.

Caplan, Z., \& Barbano, D. (2013). Shelf life of pasteurized microfiltered milk containing 2\% fat. Journal of Dairy Science, 96(12), 8035-8046. http://dx.doi.org/10.3168/jds.2013-6657. PMid:24140334.

Chandrapala, J., Oliver, C. M., Kentish, S., \& Ashokkumar, M. (2013). Use of power ultrasound to improve extraction and modify phase transitions in food processing. Food Reviews International, 29(1), 67-91. http://dx.doi.org/10.1080/87559129.2012.692140.

Cheftel, J. C. (1992). Effects of high hydrostatic pressure on food constituents: na overview. In C. Balny, R. Hayashi, K. Heremans \& P. Masson (Eds.), High pressure and biotechnology (pp. 195-209). London: Colloque INSER/Jonh Libbey Eurotext.

Chemat, F., Zill-e-Huma, \& Khan, M. K. (2011). Applications of ultrasound in food technology: processing, preservation and extraction. Ultrasonics Sonochemistry, 18(4), 813-835. http://dx.doi. org/10.1016/j.ultsonch.2010.11.023. PMid:21216174.

Chen, H., \& Hoover, D. G. (2003). Modeling the combined effect of high hydrostatic pressure and mild heat on the inactivation kinetics of Listeria monocytogenes Scott A in whole milk. Innovative Food Science \& Emerging Technologies, 4(1), 25-34. http://dx.doi. org/10.1016/S1466-8564(02)00083-8.

Choudhary, R., \& Bandla, S. (2012). Ultraviolet pasteurization for food industry. International Journal of Food Science and Nutrition Engineering, 2(1), 12-15. http://dx.doi.org/10.5923/j.food.20120201.03.

Claeys, W. L., Cardoen, S., Daube, G., De Block, J., Dewettinck, K., Dierick, K., De Zutter, L., Huyghebaert, A., Imberechts, H., Thiange, P., Vandenplas, Y., \& Herman, L. (2013). Raw or heated cow milk consumption: Review of risks and benefits. Food Control, 31(1), 251-262. http://dx.doi.org/10.1016/j.foodcont.2012.09.035.

Coutinho, N. M., Silveira, M. R., Fernandes, L. M., Moraes, J., Pimentel, T. C., Freitas, M. Q., Silva, M. C., Raices, R. S. L., Ranadheera, C. S., Borges, F. O., Neto, R. P. C., Tavares, M. I. B., Fernandes, F. A. N., Fonteles, T. V., Nazzaro, F., Rodrigues, S., \& Cruz, A. G. (2019a). Processing chocolate milk drink by low-pressure cold plasma technology. Food Chemistry, 278, 276-283. http://dx.doi.org/10.1016/j. foodchem.2018.11.061. PMid:30583374.

Coutinho, N. M., Silveira, M. R., Pimentel, T. C., Freitas, M. Q., Moraes, J., Fernandes, L. M., Silva, M. C., Raices, R. S. L., Ranadheera, C. S., Borges, F. O., Neto, R. P. C., Tavares, M. I. B., Fernandes, F. A. N.,
Nazzaro, F., Rodrigues, S., \& Cruz, A. G. (2019b). Chocolate milk drink processed by cold plasma technology: physical characteristics, thermal behavior and microstructure. LWT, 102, 324-329. http:// dx.doi.org/10.1016/j.lwt.2018.12.055.

Cregenzán-Alberti, O., Halpin, R. M., Whyte, P., Lyng, J. G., \& Noci, F. (2015). Study of the suitability of the central composite design to predict the inactivation kinetics by pulsed electric fields (PEF) in Escherichia coli, Staphylococcus aureus and Pseudomonas 1048 fluorescens in milk. Food and Bioproducts Processing, 95, 313-322.

Datta, N., Harimurugan, P., \& Palombo, E. A. (2015). Ultraviolet and pulsed light technologies in dairy processing. In N. Datta \& P. Tomasula (Eds.), Emerging dairy processing technologies: opportunities for the dairy industry (pp. 181-204). Chichester: Wiley Blackwell.

Daufin, G., Escudier, J.-P., Carrere, H., Berot, S., Fillaudeau, L., \& Decloux, M. (2001). Recent and emerging applications of membrane processes in the food and dairy industry. Food and Bioproducts Processing, 79(2), 89-102. http://dx.doi.org/10.1205/096030801750286131.

Dhakal, S., Liu, C., Zhang, Y., Roux, K. H., Sathe, S. K., \& Balasubramaniam, V.M. (2014). Effect of high pressure processing on the immunoreactivity of almond milk. Food Research International, 62, 215-222. http:// dx.doi.org/10.1016/j.foodres.2014.02.021.

Diels, A. M., Callewaert, L., Wuytack, E. Y., Masschalck, B., \& Michiels, C. W. (2005). Inactivation of Escherichia coli by highpressure homogenisation is influenced by fluid viscosity but not by water activity and product composition. International Journal of Food Microbiology, 101(3), 281-291. http://dx.doi.org/10.1016/j. ijfoodmicro.2004.11.011. PMid:15925711.

Dunn, J. E., \& Pearlman, J. S. (1987). U.S. Patent 4,695,472. Methods and apparatus for extending the shelf-life of fluid food products. San Diego, CA: Maxwell Laboratories, Inc.

Dutreux, N., Notermans, S., Wijtzes, T., Gongora-Nieto, M., BarbosaCanovas, G., \& Swanson, B. (2000). Pulsed electric fields inactivation of attached and free-living Escherichia coli and Listeria innocua under several conditions. International Journal of Food Microbiology, 54(1-2), 91-98. http://dx.doi.org/10.1016/S0168-1605(99)00175-0. PMid:10746578.

Earnshaw, R., Appleyard, J., \& Hurst, R. (1995). Understanding physical inactivation processes: combined preservation opportunities using heat, ultrasound and pressure. International Journal of Food Microbiology, 28(2), 197-219. http://dx.doi.org/10.1016/0168-1605(95)00057-7. PMid:8750667.

Elwell, M., \& Barbano, D. (2006). Use of microfiltration to improve fluid milk quality. Journal of Dairy Science, 89(Suppl. 1), E20-E30. http:// dx.doi.org/10.3168/jds.S0022-0302(06)72361-X. PMid:16527875.

Erkmen, O. (2009). Mathematical modeling of Salmonella typhimurium inactivation under high hydrostatic pressure at different temperatures. Food and Bioproducts Processing, 87(1), 68-73. http://dx.doi. org/10.1016/j.fbp.2008.05.002.

Evelyn, E., \& Silva, F. V. M. (2015). High pressure processing of milk: modeling the inactivation of psychrotrophic Bacillus cereus spores at 38-70 ${ }^{\circ} \mathrm{C}$. Journal of Food Engineering, 165, 141-148. http://dx.doi. org/10.1016/j.jfoodeng.2015.06.017.

Evrendilek, G. (2014). Non-thermal processing of milk and milk products for microbial safety. In B. Özer \& G. Akdemir-Evrendilek (Eds.), Dairy microbiology and biochemistry: recent developments. Boca Raton: CRC Press. http://dx.doi.org/10.1201/b17297-14.

Evrendilek, G. A., \& Zhang, Q. (2005). Effects of pulse polarity and pulse delaying time on pulsed electric fields-induced pasteurization of E. coli O157: H7. Journal of Food Engineering, 68(2), 271-276. http://dx.doi.org/10.1016/j.jfoodeng.2004.06.001. 
Falguera, V., Pagan, J., \& Ibarz, A. (2011). Effect of UV irradiation on enzymatic activities and physicochemical properties of apple juices from different varieties. Lebensmittel-Wissenschaft + Technologie, 44(1), 115-119. http://dx.doi.org/10.1016/j.lwt.2010.05.028.

Fernández García, L., Álvarez Blanco, S., \& Riera Rodriguez, F. A. (2013). Microfiltration applied to dairy streams: removal of bacteria. Journal of the Science of Food and Agriculture, 93(2), 187-196. http:// dx.doi.org/10.1002/jsfa.5935. PMid:23169488.

Fernández, A., \& Thompson, A. (2012). The inactivation of Salmonella by cold atmospheric plasma treatment. Food Research International, 45(2), 678-684. http://dx.doi.org/10.1016/j.foodres.2011.04.009.

Fernández-Molina, J. J., Barkstrom, E., \& Torstensson, P. (1999a). Inactivation of Listeria innocua and Pseudomonas fluorescens in skim milk treated with pulsed electric fields (PEF). New York: American Institute of Chemical Engineers.

Fernández-Molina, J., Barkstrom, E., Torstensson, P., Barbosa-Cánovas, G., \& Swanson, B. (1999b). Shelf-life extension of raw skim milk by combining heat and pulsed electric fields. In G. V. Barbosa-Cánovas \& S. Lombardo (Eds.), The 6th Conference of Food Engineering. Dallas: AIChE.

Fernández-Molina, J. J. (2001). Inactivation of Listeria innocua and Pseudomonas fluorescens in skim milk treated with pulsed electric fields. In G. V. Barbosa-Ca'novas \& Q. H. Zhang (Eds.), Pulsed electric fields in food processing. Fundamental aspects and applications (pp. 149-166). Lancaster, PA: Technomic Publishing Company Inc.

Fritsch, J., \& Moraru, C. (2008). Development and optimization of a carbon dioxide-aided cold microfiltration process for the physical removal of microorganisms and somatic cells from skim milk. Journal of Dairy Science, 91(10), 3744-3760. http://dx.doi.org/10.3168/ jds.2007-0899. PMid:18832196.

García, M. L., Burgos, J., Sanz, B., \& Ordonez, J. (1989). Effect of heat and ultrasonic waves on the survival of two strains of Bacillus subtilis. The Journal of Applied Bacteriology, 67(6), 619-628. PMid:2515184.

Gervilla, R., Felipe, X., Ferragut, V., \& Guamis, B. (1997). Effect of high hydrostatic pressure on Escherichia coli and Pseudomonas fluorescens strains in bovine milk. Journal of Dairy Science, 80, 2297-2303.

Gésan-Guiziou, G. (2010). Removal of bacteria, spores and somatic cells from milk by centrifugation and microfiltration techniques. In M. Griffiths (Ed.), Improving the safety and quality of milk (pp. 349-372). Boca Raton: CRC Press.

Gosch, T., Apprich, S., Kneifel, W., \& Novalin, S. (2014). A combination of microfiltration and high pressure treatment for the elimination of bacteria in bovine colostrum. International Dairy Journal, 34(1), 41-46. http://dx.doi.org/10.1016/j.idairyj.2013.06.014.

Grahl, T., \& Märkl, H. (1996). Killing of microorganisms by pulsed electric fields. Applied Microbiology and Biotechnology, 45(1-2), 148-157. http://dx.doi.org/10.1007/s002530050663. PMid:8920190.

Grahl, T., Sitzmann, W., \& Maèrkl, H. (1992). Killing of microorganisms in fluid media by high-voltage pulses. In DECHEMA Biotechnology Conferences. Weinheim: VCH.

Guerrero-Beltrán, J. Á., Sepulveda, D. R., Góngora-Nieto, M. M., Swanson, B., \& Barbosa-Cánovas, G. (2010). Milk thermization by pulsed electric fields (PEF) and electrically induced heat. Journal of Food Engineering, 100(1), 56-60. http://dx.doi.org/10.1016/j. jfoodeng.2010.03.027.

Guimarães, J. T., Silva, E. K., Alvarenga, V. O., Costa, A. L. R., Cunha, R. L., Sant'Ana, A. S., Freitas, M. Q., Meireles, M. A. A., \& Cruz, A. G. (2018). Physicochemical changes and microbial inactivation after high-intensity ultrasound processing of prebiotic whey beverage applying different ultrasonic power levels. Ultrasonics Sonochemistry,
44, 251-260. http://dx.doi.org/10.1016/j.ultsonch.2018.02.012. PMid:29680610.

Guimarães, J. T., Silva, E. K., Ranadheera, C. S., Moraes, J., Raices, R. S., Silva, M. C., Ferreira, M. S., Freitas, M. Q., Meireles, M. A. A., \& Cruz, A. G. (2019). Effect of high-intensity ultrasound on the nutritional profile and volatile compounds of a prebiotic soursop whey beverage. Ultrasonics Sonochemistry, 55, 157-164. http://dx.doi. org/10.1016/j.ultsonch.2019.02.025. PMid:30853535.

Guneser, O., \& Karagul Yuceer, Y. (2012). Effect of ultraviolet light on water- and fat-soluble vitamins in cow and goat milk. Journal of Dairy Science, 95(11), 6230-6241. http://dx.doi.org/10.3168/ jds.2011-5300. PMid:23084715.

Guo, J., Huang, K., \& Wang, J. (2015). Bactericidal effect of various nonthermal plasma agents and the influence of experimental conditions in microbial inactivation: a review. Food Control, 50, 482-490. http:// dx.doi.org/10.1016/j.foodcont.2014.09.037.

Gupta, S. (2011). Milk goes ultraviolet. New Scientist, 210, 19.

Halpin, R., Cregenzán-Alberti, O., Whyte, P., Lyng, J., \& Noci, F. (2013). Combined treatment with mild heat, manothermosonication and pulsed electric fields reduces microbial growth in milk. Food Control, 34(2), 364-371. http://dx.doi.org/10.1016/j.foodcont.2013.05.008.

Harte, F., Luedecke, L., Swanson, B., \& Barbosa-Canovas, G. (2003). Low-fat set yogurt made from milk subjected to combinations of high hydrostatic pressure and thermal processing. Journal of Dairy Science, 86(4), 1074-1082. http://dx.doi.org/10.3168/jds.S00220302(03)73690-X. PMid:12741531.

Harvey, E. N., \& Loomis, A. L. (1929). The destruction of luminous bacteria by high frequency sound waves. Journal of Bacteriology, 17(5), 373-376. http://dx.doi.org/10.1128/JB.17.5.373-376.1929. PMid:16559370.

Herceg, Z., Režek Jambrak, A., Lelas, V., \& Mededovic Thagard, S. (2012). The effect of high intensity ultrasound treatment on the amount of Staphylococcus aureus and Escherichia coli in milk. Food Technology and Biotechnology, 50(1), 46-52.

Higuera-Barraza, O. A., Del Toro-Sanchez, C. L., Ruiz-Cruz, S., \& Marquez-Rios, E. (2016). Effects of high-energy ultrasound on the functional properties of proteins. Ultrasonics Sonochemistry, 31, 558-562. http://dx.doi.org/10.1016/j.ultsonch.2016.02.007. PMid:26964983.

International Dairy Foods Association - IDFA. (2006). Dairy facts. Washington: IDFA.

Iucci, L., Patrignani, F., Vallicelli, M., Guerzoni, M. E., \& Lanciotti, R. (2007). Effects of high pressure homogenization on the activity of lysozyme and lactoferrin against Listeria monocytogenes. Food Control, 18, 558-565.

Jin, Y., Hengl, N., Baup, S., Pignon, F., Gondrexon, N., Sztucki, M., Gésan-Guiziou, G., Magnin, A., Abyan, M., Karrouch, M., \& Blésès, D. (2014). Effects of ultrasound on cross-flow ultrafiltration of skim milk: characterization from macro-scale to nano-scale. Journal of Membrane Science, 470, 205-218. http://dx.doi.org/10.1016/j. memsci.2014.07.043.

Kalchayanand, N., Sikes, A., Dunne, C., \& Ray, B. (1998). Factors influencing death and injury of foodborne pathogens by hydrostatic pressure-pasteurization. Food Microbiology, 15(2), 207-214. http:// dx.doi.org/10.1006/fmic.1997.0155.

Khanal, D. (2014). Non-thermal processing of skim milk: impact on microbial reduction, physico-chemical properties and quality of Brie type cheese (Ph.D. thesis). University of Guelph, Guelph.

Korachi, M., \& Aslan, N. (2011). The effect of atmospheric pressure plasma corona discharge on $\mathrm{pH}$, lipid content and DNA of bacterial 
cells. Plasma Science \& Technology, 13(1), 99-105. http://dx.doi. org/10.1088/1009-0630/13/1/20.

Korachi, M., Gurol, C., \& Aslan, N. (2010). Atmospheric plasma discharge sterilization effects on whole cell fatty acid profiles of Escherichia coli and Staphylococcus aureus. Journal of Electrostatics, 68(6), 508-512. http://dx.doi.org/10.1016/j.elstat.2010.06.014.

Kumar, P., Sharma, N., Ranjan, R., Kumar, S., Bhat, Z. F., \& Jeong, D. K. (2013). Perspective of membrane technology in dairy industry: a review. Asian-Australasian Journal of Animal Sciences, 26(9), 13471358. http://dx.doi.org/10.5713/ajas.2013.13082. PMid:25049918.

Leeb, E., Holder, A., Letzel, T., Cheison, S. C., Kulozik, U., \& Hinrichs, J. (2014). Fractionation of dairy based functional peptides using ion-exchange membrane adsorption chromatography and crossflow electro membrane filtration. International Dairy Journal, 38(2), 116-123. http://dx.doi.org/10.1016/j.idairyj.2013.12.006.

Li, S. Q., Zhang, Q., Lee, Y. Z., \& Pham, T. V. (2003). Effects of pulsed electric fields and thermal processing on the stability of bovine immunoglobulin G (IgG) in enriched soymilk. Journal of Food Science, 68(4), 1201-1207. http://dx.doi.org/10.1111/j.1365-2621.2003. tb09625.x.

Li, X., \& Farid, M. (2016). A review on recent development in nonconventional food sterilization technologies. Journal of Food Engineering, 182, 33-45. http://dx.doi.org/10.1016/j.jfoodeng.2016.02.026.

Mañas, P., Barsotti, L., \& Cheftel, J. C. (2001). Microbial inactivation by pulsed electric fields in a batch treatment chamber: effects of some electrical parameters and food constituents. Innovative Food Science \& Emerging Technologies, 2(4), 239-249. http://dx.doi.org/10.1016/ S1466-8564(01)00041-8.

Manzoor, M. F., Ahmad, N., Aadil, R. M., Rahaman, A., Ahmed, Z., Rehman, A., Siddeeg, A., Zeng, X.-A., \& Manzoor, A. (2019a). Impact of pulsed electric field on rheological, structural and physicochemical properties of almond milk. Journal of Food Process Engineering, 42(8), e13299. http://dx.doi.org/10.1111/jfpe.13299.

Manzoor, M. F., Zeng, X. Z., Rahaman, A., Siddeeg, A., Aadil, R. M., Ahmed, Z., Li, J., \& Niu, D. (2019b). Combined impact of pulsed electric field and ultrasound on bioactive compounds and FT-IR analysis of almond extract. Journal of Food Science and Technology, 56(5), 2355-2364. http://dx.doi.org/10.1007/s13197-019-03627-7. PMid:31168118.

Martin, O., Qin, B., Chang, F., Barbosa-Cánovas, G., \& Swanson, B. (1997). Inactivation of Escherichia coli in skim milk by high intensity pulsed electric fields. Journal of Food Process Engineering, 20(4), 317-336. http://dx.doi.org/10.1111/j.1745-4530.1997.tb00425.x.

Matak, K., Churey, J., Worobo, R., Sumner, S., Hovingh, E., Hackney, C., \& Pierson, M. (2005). Efficacy of UV light for the reduction of Listeria monocytogenes in goat's milk. Journal of Food Protection, 68(10), 2212-2216. http://dx.doi.org/10.4315/0362-028X-68.10.2212. PMid:16245732.

Maubois, J. (2002). Membrane microfiltration: a tool for a new approach in dairy technology. Australian Journal of Dairy Technology, 57(2), 92.

McClements, J., Patterson, M., \& Linton, M. (2001). The effect of growth stage and growth temperature on high hydrostatic pressure inactivation of some psychrotrophic bacteria in milk. Journal of Food Protection, 64(4), 514-522. http://dx.doi.org/10.4315/0362028X-64.4.514. PMid:11307889.

Michalac, S., Alvarez, V., Ji, T., \& Zhang, Q. (2003). Inactivation of selected microorganisms and properties of pulsed electric field processed milk. Journal of Food Processing and Preservation, 27(2), 137-151. http://dx.doi.org/10.1111/j.1745-4549.2003.tb00507.x.
Mir, S. A., Shah, M. A., \& Mir, M. M. (2016). Understanding the Role of Plasma Technology in Food Industry. Food and Bioprocess Technology, 9(5), 734-750. http://dx.doi.org/10.1007/s11947-016-1699-9.

Miranda, M. L. C. (1998). Inactivation of Listeria innocua by pulsed electric fields and nisin. Washington: Washington State University.

Misra, N., Koubaa, M., Roohinejad, S., Juliano, P., Alpas, H., Inacio, R. S., Saraiva, J. A., \& Barba, F. J. (2017). Landmarks in the historical development of twenty first century food processing technologies. Food Research International, 97, 318-339. http://dx.doi.org/10.1016/j. foodres.2017.05.001. PMid:28578057.

Monteiro, S. H., Silva, E. K., Alvarenga, V. O., Moraes, J., Freitas, M. Q., Silva, M. C., Raices, R. S. L., Sant'Ana, A. S., Meireles, M. A. A., \& Cruz, A. G. (2018). Effects of ultrasound energy density on the non-thermal pasteurization of chocolate milk beverage. Ultrasonics Sonochemistry, 42, 1-10. http://dx.doi.org/10.1016/j. ultsonch.2017.11.015. PMid:29429649.

Monteiro, S. H., Silva, E. K., Guimarães, J. T., Freitas, M. Q., Meireles, M. A. A., \& Cruz, A. G. (2020). High-intensity ultrasound energy density: How different modes of application influence the quality parameters of a dairy beverage. Ultrasonics Sonochemistry, 63, 104928. http://dx.doi.org/10.1016/j.ultsonch.2019.104928. PMid:31952002.

Morren, J., Roodenburg, B., \& de Haan, S. W. (2003). Electrochemical reactions and electrode corrosion in pulsed electric field (PEF) treatment chambers. Innovative Food Science \& Emerging Technologies, 4(3), 285-295. http://dx.doi.org/10.1016/S1466-8564(03)00041-9.

Naik, L., Sharma, R., Rajput, Y., \& Manju, G. (2013). Application of high pressure processing technology for dairy food preservation-future perspective: a review. Journal of Animal Production Advances, 3(8), 232-241. http://dx.doi.org/10.5455/japa.20120512104313.

Noci, F., Walkling-Ribeiro, M., Cronin, D., Morgan, D., \& Lyng, J. (2009). Effect of thermosonication, pulsed electric field and their combination on inactivation of Listeria innocua in milk. International Dairy Journal, 19(1), 30-35. http://dx.doi.org/10.1016/j.idairyj.2008.07.002.

Ojha, K. S., Mason, T. J., O’Donnell, C. P., Kerry, J. P., \& Tiwari, B. K. (2017). Ultrasound technology for food fermentation applications. Ultrasonics Sonochemistry, 34, 410-417. http://dx.doi.org/10.1016/j. ultsonch.2016.06.001. PMid:27773263.

Olesen, N., \& Jensen, F. (1989). Microfiltration - the influence of operation parameters on the process. Milchwissenschaft. Milk Science International, 44(8), 476-479.

Oliveira, S. C. T., Figueiredo, A. B., Evtuguin, D. V., \& Saraiva, J. A. (2012). High pressure treatment as a tool for engineering of enzymatic reactions in cellulosic fibres. Bioresource Technology, 107, 530-534. http://dx.doi.org/10.1016/j.biortech.2011.12.093. PMid:22244958.

Orlowska, M., Koutchma, T., Grapperhaus, M., Gallagher, J., Schaefer, R., \& Defelice, C. (2013). Continuous and pulsed ultraviolet light for nonthermal treatment of liquid foods. Part 1: effects on quality of fructose solution, apple juice, and milk. Food and Bioprocess Technology, 6(6), 1580-1592. http://dx.doi.org/10.1007/s11947012-0779-8.

Pafylias, I., Cheryan, M., Mehaia, M., \& Saglam, N. (1996). Microfiltration of milk with ceramic membranes. Food Research International, 29(2), 141-146. http://dx.doi.org/10.1016/0963-9969(96)00007-5.

Pal, M. (2017). Pulsed electric field processing: an emerging technology for food preservation. Journal of Excipients and Food Chemicals, 3(2), 1000126. http://dx.doi.org/10.4172/2472-0542.1000126.

Pankaj, S. K., Wan, Z., \& Keener, K. M. (2018). Effects of cold plasma on food quality: a review. Foods, 7(1) PMid:29301243.

Patterson, M. F., \& Kilpatrick, D. J. (1998). The combined effect of high hydrostatic pressure and mild heat on inactivation of pathogens in 
milk and poultry. Journal of Food Protection, 61(4), 432-436. http:// dx.doi.org/10.4315/0362-028X-61.4.432. PMid:9709206.

Patterson, M. F., Quinn, M., Simpson, R., \& Gilmour, A. (1995). Sensitivity of vegetative pathogens to high hydrostatic pressure treatment in phosphate-buffered saline and foods. Journal of Food Protection, 58(5), 524-529. http://dx.doi.org/10.4315/0362-028X-58.5.524. PMid:31137263.

Pereira, R. N., \& Vicente, A. A. (2010). Environmental impact of novel thermal and non-thermal technologies in food processing. Food Research International, 43(7), 1936-1943. http://dx.doi.org/10.1016/j. foodres.2009.09.013.

Picart, L., Dumay, E., \& Cheftel, J. C. (2002). Inactivation of Listeria innocua in dairy fluids by pulsed electric fields: influence of electric parameters and food composition. Innovative Food Science \& Emerging Technologies, 3, 357-369.

Picart, L., Thiebaud, M., René, M., Pierre Guiraud, J., Cheftel, J. C., \& Dumay, E. (2006). Effects of high pressure homogenisation of raw bovine milk on alkaline phosphatase and microbial inactivation: a comparison with continuous short-time thermal treatments. The Journal of Dairy Research, 73(4), 454-463. http://dx.doi.org/10.1017/ S0022029906001853. PMid:16834813.

Pina-Perez, M. C., Rodrigo, D., \& Lopez, A. M. (2009). Sub-lethal damage in Cronobacter sakazakii subsp sakazakii cells after different pulsed electric field treatments in infant formula milk. Food Control, 20, 1145-1150.

Pinho, C. R., Franchi, M. A., Tribst, A. A., \& Cristianinia, M. (2011). Effect of high pressure homogenization process on Bacillus stearothermophilus and Clostridium sporogenes spores in skim milk. Procedia Food Science, 1, 869-873.

Pothakamury, U. R., Monsalve-Gonzalez, A., Barbosa-Cánovas, G. V., \& Swanson, B. G. (1995). Inactivation of Escherichia coli and Staphylococcus aureus in model foods by pulsed electric field technology. Food Research International, 28(2), 167-171.

Pothakamury, U. R. (1995). High voltage pulsed electric field inactivation of Bacillus subtilis and Lactobacillus delbrueckii. Revista española de ciencia y tecnología de alimentos, 35(1), 101-107.

Potter, D. C. (1986). India's political administrators 1919-1983. Oxford: Clarendon Press.

Qin, B.-L., Barbosa-Canovas, G. V., Swanson, B. G., Pedrow, P. D., \& Olsen, R. G. (1998). Inactivating microorganisms using a pulsed electric field continuous treatment system. IEEE Transactions on Industry Applications, 34(1), 43-50. http://dx.doi.org/10.1109/28.658715.

Qin, B.-L., Chang, F.-J., Barbosa-Cánovas, G. V., \& Swanson, B. G. (1995). Nonthermal inactivation of Saccharomyces cerevisiae in apple juice using pulsed electric fields. Lebensmittel-Wissenschaft + Technologie, 28(6), 564-568. http://dx.doi.org/10.1016/0023-6438(95)90002-0.

Qin, B. L., Zhang, Q., Barbosa-Cánovas, G. V., Swanson, B. G., \& Pedrow, P. D. (1994). Inactivation of microorganisms by pulsed electric fields with different voltage waveforms. EEE Transactions on Dielectrics and Electrical Insulation, 1(6), 1047-1057.

Rastogi, N., Raghavarao, K., Balasubramaniam, V., Niranjan, K., \& Knorr, D. (2007). Opportunities and challenges in high pressure processing of foods. Critical Reviews in Food Science and Nutrition, 47(1), 69-112. http://dx.doi.org/10.1080/10408390600626420. PMid:17364696.

Reina, L. D., Jin, Z. T., Yousef, A. E., \& Zhang, Q. H. (1998). Inactivation of Listeria monocytogenes in milk by pulsed electric field. Journal of Food Protection, 61(9), 1203-1206.

Reinemann, D., Gouws, P., Cilliers, T., Houck, K., \& Bishop, J. (2006). New methods for UV treatment of milk for improved food safety and product quality. In 2006 ASAE Annual Meeting. St. Joseph: American Society of Agricultural and Biological Engineers. http:// dx.doi.org/10.13031/2013.21493.

Rodríguez-González, O., Walkling-Ribeiro, M., Jayaram, S., \& Griffiths, M. W. (2011). Factors affecting the inactivation of the natural microbiota of milk processed by pulsed electric fields and crossflow microfiltration. The Journal of Dairy Research, 78(3), 270-278. http://dx.doi.org/10.1017/S0022029911000367. PMid:21774851.

Roobab, U., Aadil, R. M., Madni, G. M., \& Bekhit, A. E. D. (2018). The impact of nonthermal technologies on the microbiological quality of juices: a review. Comprehensive Reviews in Food Science and Food Safety, 17(2), 437-457. http://dx.doi.org/10.1111/1541-4337.12336.

Rowan, N. J., MacGregor, S. J., Anderson, J. G., Cameron, D., \& Farish, O. (2001). Inactivation of Mycobacterium paratuberculosis by pulsed electric fields. Applied and Environmental Microbiology, 67, 2833-2836.

Ruan, R. R. (2007). Concentrated High Intensity Electric Field (CHIEF) technology for liquid food pasteurization. In IFT Annual Meeting. Chicago: Institute of Food Technologists.

Russell, N. J. (2002). Bacterial membranes: the effects of chill storage and food processing. An overview. International Journal of Food Microbiology, 79(1-2), 27-34. http://dx.doi.org/10.1016/S01681605(02)00176-9. PMid:12382682.

Saboyainsta, L. V., \& Maubois, J.-L. (2000). Current developments of microfiltration technology in the dairy industry. Le Lait, 80(6), 541-553. http://dx.doi.org/10.1051/lait:2000144.

Sarangapani, C., Devi, Y., Thirundas, R., Annapure, U. S., \& Deshmukh, R. R. (2015). Effect of low-pressure plasma on physico-chemical properties of parboiled rice. Lebensmittel-Wissenschaft + Technologie, 63(1), 452-460. http://dx.doi.org/10.1016/j.lwt.2015.03.026.

Saulis, G., Rodaitè-Riševičienè, R., \& Snitka, V. (2007). Increase of the roughness of the stainless-steel anode surface due to the exposure to high-voltage electric pulses as revealed by atomic force microscopy. Bioelectrochemistry (Amsterdam, Netherlands), 70(2), 519-523. http:// dx.doi.org/10.1016/j.bioelechem.2006.12.003. PMid:17289442.

Sensoy, I., Zhang, Q. H., \& Sastry, S. K. (1997). Inactivation kinetics of Salmonella dublin by pulsed electric field. Journal of Food Process Engineering, 20(5), 367-381. http://dx.doi.org/10.1111/j.1745-4530.1997. tb00428.x.

Sepulveda-Ahumada, D. (2003). Preservation of fluid foods by pulse electric fields in combination with mild thermal treatments (Ph.D. thesis). Washington State University, Pullman, WA.

Setlow, B., Melly, E., \& Setlow, P. (2001). Properties of spores of Bacillus subtilis blocked at an intermediate stage in spore germination. Journal of Bacteriology, 183(16), 4894-4899. http://dx.doi.org/10.1128/ JB.183.16.4894-4899.2001. PMid:11466293.

Shanmugam, A., Chandrapala, J., \& Ashokkumar, M. (2012). The effect of ultrasound on the physical and functional properties of skim milk. Innovative Food Science \& Emerging Technologies, 16, 251-258. http://dx.doi.org/10.1016/j.ifset.2012.06.005.

Shao, Y., \& Ramaswamy, H. S. (2011). Clostridium sporogenes-ATCC 7955 spore destruction kinetics in milk under high pressure and elevated temperature treatment conditions. Food and Bioprocess Technology, 4(3), 458-468. http://dx.doi.org/10.1007/s11947-0080165-8.

Sharma, P., Bremer, P., Oey, I., \& Everett, D. W. (2014). Bacterial inactivation in whole milk using pulsed electric field processing. International Dairy Journal, 35(1), 49-56. http://dx.doi.org/10.1016/j. idairyj.2013.10.005.

Shin, J. K., Jung, K. J., Pyun, Y. R., \& Chung, M. S. (2007). Application of pulsed electric fields with square wave pulse to milk inoculated 
with E. coli, P. fluorescens, and B. stearothermophilus. Food Science and Biotechnology, 16, 1082-1084.

Sierra, I., Vidal, V., \& López, F. (2000). Effect of high pressure on the vitamin B1 and B6 content of milk. Milchwissenschaft. Milk Science International, 55(7), 365-367.

Simmons, M. J., Alberini, F., Tsoligkas, A. N., Gargiuli, J., Parker, D. J., Fryer, P. J., \& Robinson, S. (2012). Development of a hydrodynamic model for the UV-C treatment of turbid food fluids in a novel 'SurePure turbulator ${ }^{\mathrm{Tw}}$ swirl-tube reactor. Innovative Food Science \& Emerging Technologies, 14, 122-134. http://dx.doi.org/10.1016/j. ifset.2011.11.006.

Simpson, R., \& Gilmour, A. (1997). The resistance of Listeria monocytogenesto high hydrostatic pressure in foods. Food Microbiology, 14(6), 567573. http://dx.doi.org/10.1006/fmic.1997.0117.

Smelt, J. (1998). Recent advances in the microbiology of high pressure processing. Trends in Food Science \& Technology, 9(4), 152-158. http://dx.doi.org/10.1016/S0924-2244(98)00030-2.

Sobrino-López, A., \& Martin-Belloso, O. (2006). Enhancing inactivation of Staphylococcus aureus in skim milk by combining high-intensity pulsed electric fields and nisin. Journal of Food Protection, 69(2), 345353. http://dx.doi.org/10.4315/0362-028X-69.2.345. PMid:16496575.

Sobrino-López, A., \& Martín-Belloso, O. (2008). Enhancing the lethal effect of high intensity pulsed electric field in milk by antimicrobial compounds as combined hurdles. Journal of Dairy Science, 91, $1759-1768$.

Soria, A. C., \& Villamiel, M. (2010). Effect of ultrasound on the technological properties and bioactivity of food: a review. Trends in Food Science \& Technology, 21(7), 323-331. http://dx.doi.org/10.1016/j. tifs.2010.04.003.

Sousa, S. G., Delgadillo, I., \& Saraiva, J. A. (2016). Human milk composition and preservation: evaluation of high-pressure processing as a nonthermal pasteurization technology. Critical Reviews in Food Science and Nutrition, 56(6), 1043-1060. http://dx.doi.org/10.1080/ 10408398.2012.753402. PMid:25313944.

Stewart, C. M., Dunne, C. P., Sikes, A., \& Hoover, D. G. (2000). Sensitivity of spores of Bacillus subtilis and Clostridium sporogenes PA 3679 to combinations of high hydrostatic pressure and other processing parameters. Innovative Food Science \& Emerging Technologies, 1(1), 49-56. http://dx.doi.org/10.1016/S1466-8564(00)00004-7.

Swanson, B. G., Monsalve-Gonzalez, A., Pothakamury, U., \& BarbosaCánovas, G. V. (1995). High voltage pulsed electric field inactivation of" Bacillus subtilis" and" Lactobacillus delbrueckii. Revista Española de Ciencia y Tecnología de Alimentos, 35(1), 101-107.

Syed, Q. A., Ishaq, A., Rahman, U. U., Aslam, S., \& Shukat, R. (2017). Pulsed electric field technology in food preservation: a review.
Journal of Nutritional Health \& Food Engineering, 6(5), 168-172. http://dx.doi.org/10.15406/jnhfe.2017.06.00219.

Töpfl, S. (2006). Pulsed Electric Fields (PEF) for permeabilization of cell membranes in food-and bioprocessing: applications, process and equipment design and cost analysis (Ph.D. thesis). Technische Universität Berlin, Berlin.

Trouvé, E., Maubois, J. L., Piot, M., Madec, M. N., Fauquant, J., Rouault, A., Tabard, J., \& Brinkman, G. (1991). Retention of various microbial species during milk purification by cross-flow microfiltration. Le Lait, 72, 327-332.

Vachon, J., Kheadr, E. E., Giasson, J., Paquin, P., \& Fliss, I. (2002). Inactivation of foodborne pathogens in milk using dynamic high pressure. Journal of Food Protection, 65(2), 345-352. http://dx.doi. org/10.4315/0362-028X-65.2.345. PMid:11848566.

Viazis, S., Farkas, B., \& Jaykus, L. (2008). Inactivation of bacterial pathogens in human milk by high-pressure processing. Journal of Food Protection, 71(1), 109-118. http://dx.doi.org/10.4315/0362028X-71.1.109. PMid:18236670.

Wrigley, D. M., \& Llorca, N. G. (1992). Decrease of Salmonella typhimurium in skim milk and egg by heat and ultrasonic wave treatment. Journal of Food Protection, 55(9), 678-680. http://dx.doi. org/10.4315/0362-028X-55.9.678. PMid:31084132.

Zenker, M., Heinz, V., \& Knorr, D. (2003). Application of ultrasound assisted thermal processing for preservation and quality retention of liquid foods. Journal of Food Protection, 66, 1642-1649.

Zhang, Q., Barbosa-Cánovas, G. V., \& Swanson, B. G. (1995). Engineering aspects of pulsed electric field pasteurization. Journal of Food Engineering, 25(2), 261-281. http://dx.doi.org/10.1016/02608774(94)00030-D.

Zhang, Q. H., Qin, B. L., Barbosa-Canovas, G. V., \& Swanson, B. G. (1994). Inactivation of E. coli for food pasteurization by high-strength pulsed electric fields. Journal of Food Processing and Preservation, 19, 103-118.

Zhao, L., Zhang, S., Uluko, H., Liu, L., Lu, J., Xue, H., Kong, F., \& Lv, J. (2014). Effect of ultrasound pretreatment on rennet-induced coagulation properties of goat's milk. Food Chemistry, 165, 167-174. http://dx.doi.org/10.1016/j.foodchem.2014.05.081. PMid:25038663.

Zhao, W., Yang, R., Shen, X., Zhang, S., \& Chen, X. (2013). Lethal and sublethal injury and kinetics of Escherichia coli, Listeria monocytogenes and Staphylococcus aureus in milk by pulsed electric fields. Food Control, 32(1), 6-12. http://dx.doi.org/10.1016/j.foodcont.2012.11.029.

Zia, S., Khan, M. R., Zeng, X.-A., Sehrish, Shabbir, M. A., \& Aadil, R. M. (2019). Combined effect of microwave and ultrasonication treatments on the quality and stability of sugarcane juice during cold storage. International Journal of Food Science \& Technology, 54(8), 2563-2569. http://dx.doi.org/10.1111/ijfs.14167. 